\title{
Antiquarianism: A Reinterpretation
}

Kelsey Jackson Williams

Accepted for publication in Erudition and the Republic of Letters, published by Brill.

Antiquarianism, the early modern study of the past, occupies a central role in modern studies of humanist and post-humanist scholarship. Its relationship to modern disciplines such as archaeology is widely acknowledged, and at least some antiquaries--such as John Aubrey, William Camden, and William Dugdale--are well-known to Anglophone historians. But what was antiquarianism and how can twenty-first century scholars begin to make sense of it? To answer these questions, the article begins with a survey of recent scholarship, outlining how our understanding of antiquarianism has developed since the ground-breaking work of Arnaldo Momigliano in the mid-twentieth century. It then explores the definition and scope of antiquarian practice through close attention to contemporaneous accounts and actors' categories before turning to three case-studies of antiquaries in Denmark, Scotland, and England. By way of conclusion, it develops a series of propositions for reassessing our understanding of antiquarianism. It reaffirms antiquarianism's central role in the learned culture of the early modern world; and offers suggestions for avenues which might be taken in future research on the discipline.

\section{Antiquarianism: The State of the Field}

The days when antiquarianism could be dismissed as 'a pedantic love of detail, with an indifference to the result' have long since passed; their death-knell was rung by Arnaldo Momigliano in his pioneering 1950 'Ancient History and the Antiquarian'. ${ }^{1}$ Momigliano 
asked three simple questions: What were the origins of antiquarianism? What role did it play in the eighteenth-century 'reform of historical method'? Why did the distinction between antiquarianism and history collapse in the nineteenth century? The answers he gave continue to underpin the study of the discipline today. Antiquarianism had its origins, he wrote, in the ancient world, first amongst the Greeks, but reaching 'perfection' with Varro, whose way of investigating the past was rediscovered and imitated from the very beginning of the Renaissance. By the eighteenth century, this now flourishing discipline found itself simultaneously challenged, as historians began to appropriate antiquarian techniques, and lauded, as it provided a methodological escape from Pyrrhonism whose doubts appeared to threaten the entire edifice of ancient history. Over the course of the century, however, antiquaries were drawn into the battle between érudits and philosophes, suffering with the former, only to finally vanish in the nineteenth century when they were subsumed into a new, largely Germanic, vision of history which realized 'that erudition and philosophy were not incompatible'.

Momigliano developed this narrative in the Sather Lectures, given at the University of California, Berkeley in 1962, and sketched a lively portrait of the antiquary: 'the type of man who is interested in historical facts without being interested in history'. Here, he drew a more critical picture of antiquarianism, starkly separating it from history. Antiquaries 'distrusted literary tradition, disliked theological controversy, and had little use for ordinary political history', but most of all they 'loved disparate and obscure facts' ${ }^{4}$ In the end, Momigliano did not utterly reject the older conception of the antiquary's 'pedantic love of detail'. He added an additional important qualifier: where the historian organized their work in chronological order, the antiquary was tied to a 
systematic order and collected 'all the items that are connected with a certain subject, whether they help to solve a problem or not' 5

Momigliano's master narrative is worth rehearsing for its immense influence on subsequent scholarship which, almost without exception, has positioned itself in relation to this single foundational text. Building on it, the past two decades have seen a flowering of antiquarian scholarship, some focused on individual scholars, regions, or periods, some taking transnational, transcultural, or global approaches. Leading scholars in this renaissance include T. J. Cornell, Rebecca Gould, Anthony Grafton, Chantal Grell, Ingo Herklotz, Thomas DaCosta Kaufmann, Peter N. Miller, Jan Marco Sawilla, Alain Schnapp, Angus Vine, and Markus Völkel, amongst others, all of whom have made major contributions to the study of antiquarianism in the Momiglianian tradition and all of whom have proposed significant revisions to Momigliano's narrative. Miller's work, which developed from a long-term study of the seventeenth-century French antiquary Nicolas-Claude Fabri de Peiresc, has addressed Momigliano's legacy directly as well as challenging some of its claims. ${ }^{6}$ Referring to the elder scholar's lament that he wished he ‘could simply refer to a History of Antiquarian Studies', Miller has acknowledged the seeming impossibility of the task; nonetheless, he has offered two major contributions towards just such a work in his 'Major Trends in European Antiquarianism' and 'A Tentative Morphology of European Antiquarianism, 1500-2000'. In the former, he laid out what is currently the most detailed account of early modern antiquarianism from the fifteenth to the beginning of the seventeenth centuries; in the latter, he convincingly argued that, pace Momigliano, antiquarianism was alive and well long into the nineteenth century, only fragmenting into art history, anthropology, archaeology, sociology, and the 
other cultural sciences towards the century's end. ${ }^{8}$ Indeed, antiquarianism had existed in recognizable form almost into the time of Momigliano's own teachers and had certainly informed the comprehensive, but neglected, survey of the discipline by Karl Bernhard Stark which Momigliano himself had drawn upon in his 1950 article. ${ }^{9}$ T. J. Cornell has gone a step further in his own interrogation of Momigliano's work, drawing out the latter's 'contention that the features that separate us from the classical historians are precisely those that bring us close to the antiquarians $\cdot{ }^{10}$ For Cornell, modern historians have inherited the legacies of both antiquarianism and narrative history, but 'the distinction between the historian and the antiquarian is dead because there is no longer any justification for the exclusive definition of history as political theory in the Thucydidean sense'. ${ }^{11}$

The work of Miller and Cornell on the legacy of antiquarianism complicated one aspect of Momigliano's story; Anthony Grafton's exploration of the early modern ars historica complicated another. Momigliano saw antiquarianism and history running essentially in parallel until their spectacular merger in the erudition of Gibbon's Decline and Fall, but Grafton has shown that the reality of earlier historical writing was not so clear cut. ${ }^{12}$ The sixteenth-century jurist Jean Bodin had argued for the essential role of antiquarianism in writing history as early as 1566 , and this at times uneasy, but often fruitful, relationship continued through subsequent epochs, becoming enshrined as historical orthodoxy by Christian Gottlob Heyne a decade before Gibbon first put pen to paper. ${ }^{13}$ More broadly, Grafton's exploration of the early modern Republic of Letters has encouraged the disciplines practiced by its inhabitants to be read across each other, demonstrating that theology and technical chronology, philology and antiquarianism, 
overlapped in ways alien to modern scholarship.$^{14}$ In declaring that 'antiquaries ... inhabited one province of a larger intellectual society', Grafton has re-emphasized the importance of taking an interdisciplinary approach to the study of the early modern disciplines..$^{15}$ Meanwhile, Jan Marco Sawilla has investigated the ars historica from another angle to suggest that the most pertinent distinction between history and antiquarianism for early moderns was, at least at first, the question whether or not the author was an eyewitness or simply, in Bodin's words, 'washing dirt off old books'. ${ }^{16}$ Momigliano's air-tight distinctions, especially the distinction between synchronous and diachronous approaches, are simply not reflected in the sources explored by these two scholars.

While Grafton and Sawilla have problematized the relationship between antiquarianism and history in humanist scholarship, Chantal Grell has achieved a similar problematization in her study of the rival methodologies of 'erudition' and 'philosophy' in the Enlightenment. ${ }^{17}$ Returning to Momigliano's narrative, he saw these two approaches as each in themselves insufficient, with the érudits hopelessly mired in antiquarian detail and with the philosophes making grand but unsupportable claims about human history; only with their unification, which Momigliano located with Gibbon, could they produce modern history. Grell's study of the French picture, however, is rather different. While broadly agreeing with the consensus that erudition's stock was low for much of the eighteenth century, she saw in this neither a triumph for the philosophes nor a sublimation of erudition into philosophical history, but rather a temporary aberration. Subsequent generations of French historians in the nineteenth century, though they may not have admitted it, were far more indebted to the érudits for their methods than to 
Voltarie and Montesquieu. Grell's study calls into question not only the axial position assigned to Gibbon, but also the longer term ebb and flow of antiquarianism's stock across the past three centuries. Complementary to her work is Markus Völkel's reassessment of historical Pyrrhonism, particularly in its German context. ${ }^{18}$ Völkel takes issue with Momigliano's assessment of antiquarianism's key role in the seventeenth- and eighteenth-century debates over the nature of historical truth, suggesting instead that the 'surmounting' of the Pyrrhonist problem came through criticism, not antiquarianism per se.

These investigations into the ars historica, the Republic of Letters, and its aftermath have also been enriched by Ingo Herklotz's engagement with antiquarianism through the lens of the seventeenth-century Italian antiquary Cassiano Dal Pozzo's museo cartaceo. ${ }^{19}$ In his 'critical review' of 'Ancient History and the Antiquarian', Herklotz not only challenged Momigliano's strict division of antiquarianism and history--in what by now has become a standard move--but also suggested that this binary might not even be the most appropriate one; antiquarianism has as good a claim of being the sister discipline of philology, or even better. ${ }^{20}$ Herklotz stands out for his attention to the textual, rather than the artefactual, side of antiquarianism--something downplayed in many studies--as well as for his argument that antiquarianism's prestige was already on the decline by the end of the seventeenth century, even as it continued to flourish and expand its scholarly remit.

The relationship between antiquarian research and its expression through the written word has been further developed by Angus Vine. ${ }^{21}$ While Herklotz focused on the technical, philological side of the equation, Vine has explored the points at which 
antiquarianism became imaginative, creative, and literary in seventeenth-century England. This welcome contribution to the field not only points towards the fruitfulness of studying antiquarianism in a literary context--an endeavour whose rewards are obvious to any student of Michael Drayton's Poly-Olbion or Ferdinand von Fürstenberg's Monumenta Paderbornensia--but also pushes back against the often unspoken, but widespread, assumption that 'antiquarianism' inevitably means a deficiency in literary style. ${ }^{22}$ Vine's study is part of a larger trend which seeks to link antiquarianism with a wide variety of modern scholarly disciplines. Equally important has been Thomas DaCosta Kaufmann's investigation into the antiquarian origins of art history. ${ }^{23}$ Building on earlier studies linking the history of art and connoisseurship to antiquarianism, Kaufmann has deconstructed the myth of Johann Joachim Winckelmann's alleged invention of art history. ${ }^{24}$ Instead, he argues, Winckelmann was only one link in a much longer line of German antiquaries who paid particular attention to the history of art and artists, from whom he singles out Joachim von Sandrart (1606-1688) as a key exemplar. ${ }^{25}$ Kaufmann's work has opened up important new avenues for the study of Kunstgeschichte, but also contains more general observations relevant to the reassessment of antiquarianism as a whole, especially his forceful and convincing argument that 'the evidence ... also suggests that a revision of interpretations which hypothesize a rupture between the supposedly modern pursuits of the eighteenth century, specifically its presumed revolution in historiography, and earlier forms of scholarship, including antiquarianism and encyclopedism, is in order' ${ }^{26}$ In making this argument, he joins the growing consensus which rejects a narrative of paradigm shift from early modern to 
modern disciplinary practice in favour of a more nuanced and gradual change in scholarship.

No review of developments in antiquarian studies would be complete without considering the ground-breaking studies of antiquarianism in the longue durée and across cultures. Alain Schnapp pioneered this approach with his Conquête du passé, a study of archaeological practices across millennia; recent edited collections such as his World Antiquarianism and Peter Miller and François Louis's Antiquarianism and Intellectual Life in Europe and China, 1500-1800 have expanded antiquarianism's remit to include scholarly practices in East Asia, India, the ancient near east, and elsewhere. ${ }^{27}$ While these works do not directly confront the Momiglianian narrative in quite the same way, by expanding our definition of antiquarianism to other cultures and other times they offer new perspectives on just what was occurring in early modern scholarly life, how that can be related to the classical past, and how those same impulses have continued into the present. In doing so, they confirm the point already made by Miller: antiquarianism did not vanish because it had been subsumed by history, but rather 'antiquarianism as a methodological force 'disappeared' because it had conquered history'; as in Cornell's reading of Momigliano, the narrative history grounded in rhetoric which was familiar to the early moderns is far more distant from our own conception of historical scholarship than the works of early modern antiquaries. ${ }^{28}$

Finally, one of the boldest and most methodologically wide-reaching contributions to the post-Momiglianian study of antiquarianism has been Rebecca Gould's 2014 reassessment of the discipline as a contingent, globalizing alternative to traditional historical enquiry. ${ }^{29}$ Gould focuses on Momigliano's distinction between the 
methods of Herodotus (in her reading, the antiquary par excellence) and Thucydides (the poster boy for traditional historical writing), but goes further to explore a 1987 observation by Momigliano that examining the career of Michel Foucault 'is the best way to indicate what the Herodotian tradition can still produce' ${ }^{30}$ For Gould, Herodotus and Foucault are both working within the antiquarian 'realms of minute knowledge' and of 'events in their singularity'. ${ }^{31}$ Ultimately, she finds antiquarianism to be the double and the opposite of history: 'the value of antiquarianism lies less in its actual yield than in the paths it forges for new forms of intellectual inquiry. Antiquarianism enables the persistent critique of history. It helps us read history against itself' ${ }^{32}$ While intellectually stimulating, the 'antiquarianism' of Gould's essay is very much ideal and abstract, bearing only a partial resemblance to the antiquarian scholarship of early modern Europe. For Gould, the concept of antiquarianism is important, but we should be wary of assuming that this concept can be unproblematically related to the lived scholarship of the past.

Now, more than sixty years on, Momigliano's interpretation remains both foundational and substantially revised by later generations of scholars. The relationship between history and antiquarianism postulated by him has been effectively demolished by Grafton's exploration of the role of antiquarianism in the Renaissance ars historica, Sawilla's thought-provoking distinction between the historian as eyewitness and the antiquary as archaeologist, and Schnapp and others' recognition that the work of the modern historian is closer to that of the antiquary than to their early modern forebears. Meanwhile, the seemingly self-evident pairing of antiquarianism with history has been destabilized by the work of Miller (linking it to the modern social sciences), Herklotz 
(associating it with philology), and Kaufmann (identifying it as the origin point for art history). Likewise, almost every aspect of Momigliano's narrative of antiquarian morphologies during the seventeenth and eighteenth centuries has come under criticism. Völkel has questioned its central role in the Pyrrhonist controversy; Grell has reassessed the durability of érudit traditions leading from the early modern period into the nineteenth century; Miller, Kaufmann, and many others have deconstructed the narrative of a great methodological shift, or rupture, in the eighteenth century, identifying instead continuities leading into the nineteenth century and up to the present day. Most radically, Miller has amply proven the extent to which antiquarianism, in the formation of the modern discipline, has 'conquered' history rather than the other way round.

In the midst of this emerging post-Momiglianian consensus, I pretend neither to write the 'History of Antiquarian Studies' nor to supplant the powerful and convincing narratives offered by the scholars discussed above: my inspiration is Momigliano's own modest caveat that his work was 'a very provisional map of a field that needs much detailed exploration'. ${ }^{33}$ In the remainder of the present article, I seek to build upon the existing literature by asking three questions: what is antiquarianism (a seemingly simple question which needs to be asked anew), what was its scope, and how can we, as modern scholars, make sense of it? While gesturing to earlier and later examples, I endeavour to systematically answer these questions only for the antiquarian golden age of the seventeenth and eighteenth centuries; if they were asked of the fifteenth century or the nineteenth, the answers would be very different. Likewise, in the case studies used throughout the article, I draw upon my own experience studying the antiquarianism of northern and western Europe; another story could be written from the vantage point of 
Siena or Belgrade. Nonetheless, as antiquarianism as an analytical category is applied to more and more scholarly practices around the world, there is an increasing need to understand the early modern European discipline which gave rise to the term--not simply as a vaguely defined study of material artefacts but in precise actors' categories which illuminate its shifting, unstable, but tremendously innovative nature. The present article attempts to do this by returning to some of the questions first posed by Momigliano, providing new answers and suggesting where future antiquarian scholarship might lead.

\section{What is Antiquarianism?}

Antiquarianism did not exist in the early modern period--paradoxical as it sounds. The first known use of the word 'antiquarianism' in English was in or about March 1761, when the theological controversialist and friend of Alexander Pope, William Warburton, wrote to Richard Hurd, another ecclesiastic with literary pretensions. 'Antiquarianism', Warburton wrote, 'is, indeed, to true letters what specious funguses are to the oak; which never shoot out and flourish, till all the vigour and virtue of that monarch of the grove be effete and near exhausted ${ }^{34}$ A few years later, in 1768 , Warburton wrote of the antiquary Charles Lyttelton, Bishop of Carlisle: he 'used to despise him for his Antiquarianism; but of late, since I grow old and dull myself, I cultivated an acquaintance with him for the sake of what formerly kept us asunder' ${ }^{35}$ Already the tone which would later be used by Sir Walter Scott in recalling 'trifling discussions about antiquarian old-womanries' is set and 'antiquarianism' is on course to becoming the term of abuse which it would remain for most of the nineteenth and twentieth centuries. ${ }^{36}$ 
So what was antiquarianism before this? English was not unusual in having no word to describe the discipline; early modern French, Spanish, Italian, Portuguese, Danish, Dutch, Swedish, and German were all in the same boat. Instead they had words for the practitioner--antiquary, antiquaire, anticuario, antiquàrio, antiquário, antikvar, oudheidkundige, antikvarie, antiquar--almost all derived from the Latin antiquarius. The only phrase which might have equated to the later sense of antiquarianism was studium antiquitates, the study of antiquities. However, the extent to which studium antiquitates can be unproblematically equated with antiquarianism is far from certain. Isaac Casaubon, for example, wrote to Claude Saumaise in 1612 that 'the soundest part of all of the Reformation is that in England. Where with a zeal for truth there is also a zeal for antiquity [studium Antiquitatis] $\cdot{ }^{37}$ Here, Casaubon simply meant that the Anglican church had a due appreciation for the antiquity of Christian practice, not that its members literally focused on the study of antiquities, sacred or secular--and it seems likely that many other uses of the term had a similar broad meaning..$^{38}$ In a few instances, however, the phrase does approach the meaning of 'antiquarianism'.For example, William Camden described how 'I always had my mind bent like a tensed bow on the study of antiquities', and William Somner wrote on his own epitaph: 'ita mores antiquos Studium Antiquitatis efformat' ${ }^{39}$ Nonetheless, for much of the early modern period the practice of antiquarianism was more likely to be located in the person of the antiquary than in an abstract disciplinary concept.

This does not necessarily imply the absence of a discipline or a concept which can be identified with modern conceptions of antiquarianism. It does, however, suggest that we should foreground the practitioner, the antiquaries themselves, and recognize that 
their practice was inherently porous in its disciplinary boundaries; it could mean significantly different things at different times. Once we distinguish between the label and the set of practices, much that was unclear about the history of antiquarianism can be seen in a new light. To do this, however, first requires an interrogation of the linguistic root from which the label sprung.

Antiquarius was an uncommon word in the classical corpus and was almost certainly first brought to the notice of early moderns through its appearance in two earlyrecovered and widely-read texts: Juvenal's Satires (editio princeps, c. 1468-69) and Suetonius's Lives of the Twelve Caesars (editio princeps, 1470). ${ }^{40}$ Juvenal's sixth satire lampooned an antiquaria, a learned woman who 'is for ever consulting and poring over the 'Grammar' of Palaemon, who observes all the rules and laws of language, who quotes from ancient poets that I never heard of'; Suetonius in his life of Augustus described how Augustus 'looked on innovators [cacozelos] and archaizers [antiquarios] with equal contempt, as faulty in opposite directions'. ${ }^{41}$ Set alongside these, we may place another text, a line from St. Jerome's Epistle to Florentius in which he offered his correspondent copies of manuscripts in his possession, assuring him that 'I have students who are skilled in the ars antiquaria', in this case the art of copying manuscripts. ${ }^{42}$ All three of these pivotal appearances of the Latin word associate it with manuscripts and language; two of them have pejorative connotations of the antiquarius as a pedant or an intentional archaiser.

Alongside these definitions in the classical and patristic corpuses, there existed a post-classical use of the term in line with the quote from St. Jerome above which was itself first recovered and identified by early antiquaries. As Sawilla has discussed, Guido 
Panciroli in his De magistratibus municipalibus (1593) described the Byzantine tabularium or antiquarium, a form of public archive, as well as the role of the antiquarius, or chancellery official who preserved and copied public manuscripts. ${ }^{43}$ This sense of the antiquarius as a scribe also appears in the poems of Ausonius as glossed by Joseph Justus Scaliger ${ }^{44}$ In other words, antiquarius first meant something much closer to a philologist, a scribe, or an archivist, than to an antiquary. The first of these definitions was revived in the early modern period and continued well into the sixteenth century, such as when Robert Estienne in 1531 defined antiquarius as one 'who loves to use antiquated words' ${ }^{45}$

Alongside these older definitions, there emerged a newer concept of antiquarius as a student of antiquitates, the--often material--remains of the ancient world. This latter word consciously echoed classical works such as Varro's Antiquitates rerum humanarum et divinarum and by association the antiquarius become one who followed Varro's eclectic and wide-ranging approach to the study of past ages. Felice Feliciano described himself as antiquarius in an epigraphical context as early as 1464; by 1583 the publisher of Johannes Rosinus's textbook of Roman antiquities, the Romanarum antiquitatum libri decem, was piously wishing that the study of antiquitates by antiquarii might itself become an $\operatorname{ars} .{ }^{46}$ Crucially, however, this did not happen. Antiquarius and its vernacular cognates remained fundamentally ambiguous terms, suggesting a scholar with a commitment to the study of the past, probably the ancient past, but leaving the subject of that scholar's studies and the nature of his methods tantalizingly obscure. The first volume of the Encyclopédie (1751) was more precise in its definition of the modern antiquaire--'a person who attends to the research and study of ancient monuments, such 
as ancient medals, books, statues, sculptures, inscriptions, in a word that which can give some light to the subject'--but retained both the earlier definition of antiquarius as scribe and added to it a further classical definition, possibly spurious, of the antiquarius as a scholarly cicerone "whose function was to show the antiquities of a town to strangers, to explain ancient inscriptions, and to assist them with all their power in that kind of scholarship' ${ }^{47}$

Does this mean that we cannot define antiquarianism? That Momigliano's longedfor 'History of Antiquarian Studies' would have been the history of a discipline which never existed? No. While the purview of the antiquary altered dramatically between 1450 and 1850 , a corpus of antiquarian research and practice which preserved a memory of itself during that period nonetheless existed. In individual contexts, the definition varied from time to time and place to place, so that someone who would be an antiquary in Sweden in 1650 might not have been defined as one in Scotland in 1550; yet as the seventeenth century wore on, there was an increasing consensus that certain relatively clearly delimited spheres of enquiry fell properly to the antiquary's lot.

\section{The Extent of Antiquarianism}

To understand the antiquary's field of enquiry in contemporaneous terms, an essential first port of call is the immense repertory of scholarly bibliographies and compendia produced in the seventeenth and eighteenth centuries. The bibliographer and philologist Johann Albert Fabricius's Bibliographia Antiquaria was first published in 1713, went into a second edition in 1716, and was vastly expanded and corrected by Paul 
Schaffshausen in 1760 . Yet it was only one of many reference works. ${ }^{48}$ The Ragusan scholar Anselmo Banduri produced an elaborate bibliography of numismatics as a preface to his 1718 Numismata Imperatorum Romanorum which was subsequently expanded and published separately by Fabricius in the following year, while Johann Hübner produced a similar work for genealogical studies in 1729; the Danish diplomat Gerhard Ernst Franck de Franckenau compiled a 1,490-item bibliography of antiquarian texts dealing with Spain alone in $1724 .^{49}$ At the same time new, collected editions of canonical antiquarian texts became increasingly common. Johann Georg Graevius's Thesaurus Antiquitatum Romanarum began the tradition in 1694; subsequent Thesauri covering Greece, France, Italy, Germany, and the church, among others, carried into the following century. ${ }^{50}$ How did these works define the antiquary's scope?

At first Fabricius's Bibliographia seems chaotic: twenty-three chapters covering everything from funerals to banquets, oracles to poll taxes. Closer examination, however, reveals a hidden order. For Fabricius, philology was the queen of disciplines, but alongside it was antiquarianism 'which leaves nothing unseen in ancient writings', which studies both fables and true history, whether civil, ecclesiastical, literary, or natural, and which includes in its remit 'sacred, political, military, and private ancient rites and customs' derived both from 'ancient monuments' and from books. ${ }^{51}$ This impressive range of material was echoed across the Bibliographia, beginning with four chapters covering general works on Hebrew, Near Eastern, Greek, Roman, and Christian antiquities, and a further chapter on the 'two eyes of history'--geography and chronology-before treating first sacred antiquities, then profane antiquities subdivided into public 
matters (laws, assemblies, censuses, weights and measures, military affairs, etc.) and private affairs (clothing, banquets, childhood, domestic utensils, funerals, etc.).

In choosing to organize his bibliography along these lines, Fabricius was tapping into a well-established antiquarian tradition. His grand divisions of res divinae and res humanae, together with the subsequent subdivision of publicae and privatae, had origins which dated back to the Roman Republic. The separation of divine and human affairs into distinct categories of enquiry seems to have originated with Varro, whose Antiquitates rerum humanarum et divinarum were known only in fragments in the early modern period, but which, perhaps for that very reason, exerted an immense influence on how subsequent antiquarian research was structured and conceptualized.$^{52}$ By contrast, the subdivision of human affairs into public and private seems to have been derived from the ius publicum and ius privatum of Roman law. As early as the fifteenth century, Flavio Biondo had adopted a slight variation on this system for his Roma Triumphans (1459), dividing the work into antiquitates publicae, privatae, sacrae, et militares; a similar division--excluding the private--appears in Rosinus's 1583 handbook of Roman antiquities ${ }^{53}$ By the seventeenth century, this method of dividing the studies of the antiquary by subject matter had become sufficiently standard so that Carlo Dati, in his 1664 Synopsis of Cassiano dal Pozzo's museo cartaceo could organize the antiquary's collection as a Ramist diagram with divisions into divine and human and, within the latter, first peace and war, then within peace public and private. ${ }^{54} \mathrm{~A}$ similar division appears in Bernard de Montfaucon's Antiquité expliquée. Examples of Varronian organisation of antiquarian texts can be easily multiplied..$^{55}$ 
The significance of this structural framework lay in the vast reach it gave to the antiquary's studies. Religious history of any kind was joined with the history of customs, technology, scholarship, and almost every aspect of the civilisations of the ancient world. This capacious definition--which can still elicit a certain discomfort from modern scholars--underpinned other seemingly baffling categorizations, such as the presence of Edward Herbert of Cherbury's sceptical De religione gentilium filed under the category of libri antiquarii in the 1725 sale catalogue of the library of Cardinal Guillaume Dubois. ${ }^{56}$ In a Varronian conceptualization, antiquaries came close to claiming as their own every aspect of the study of the past except for pure philology and rhetorical, narrative history.

But a Varronian division by subject was only one possible way of organizing antiquarian studies. As the corpus of printed descriptions, images, and analyses of inscriptions, coins, vases, statues, and other relics of the ancient past grew ever greater, an organization by object began to make increasingly good sense. In the methodologically pioneering preface to his 1685 Miscellanea eruditae antiquitatis, Jacques Spon recast the studies of the antiquary into the discipline of archaeologia sive archaeographia, the study of ancient monuments, and subdivided it into eight sections by type of artefact studied. ${ }^{57}$ These covered coins, epigraphy, architecture, statues and pictures, carved gems, bas-reliefs, manuscripts, and a final catch-all which Spon dubbed angeiographia: 'the study of all domestic utensils, military items, nautical items, vases, weights and measures ${ }^{58}$ This was a dramatic departure from the Varronian mainstream and Spon softened his radicalism somewhat by proposing that certain 'subordinate sciences' such as the study of banquets, clothing, slaves, and funerals might be practiced 
alongside his new disciplinary divisions ${ }^{59}$ These were, of course, all mainstays of the Varronian subject-based schemes.

Similarly, Charles César Baudelot de Dairval, another French antiquary, organized his 1686 advice to the antiquarian traveller in a style strongly reminiscent of Spon's work published the previous year. ${ }^{60}$ After a lengthy preface discussing the importance of travel, both in general terms and for antiquarian study, he discussed, object by object: coins, inscriptions, statues, architecture, talismans and other small artefacts, manuscripts, and medals. The influence of this divergent organizational structure can be seen in subsequent works, such as Daniel Georg Morhof's Polyhistor, which by its 1732 edition subdivided antiquarian writings into traditional Varronian categories such as 'clothing', 'military matters', or 'games', but also 'writings on numismatics' or 'cups, chairs, bells, vehicles, brooches, and other domestic utensils' ${ }^{61}$ This mixed framework, privileging some aspects of the Varronian model and some of Spon's revision, appears to have won out in the end, if the twenty-four disciplines of Altertumswissenschaft enumerated by Friedrich August Wolf in 1807 can be taken as another manifestation of the same tradition. ${ }^{62}$ There, traditionally Varronian ideas such as 'the history of conditions, constitutions, and customs amongst the principal countries and people of Greece' rub shoulders with characteristically Sponiste categories such as architecture, numismatics, and epigraphy, not to mention historia literaria. ${ }^{63}$

All of these elaborate schemes must be taken with a grain of salt, however. They were designed to facilitate the study of Greek and Roman antiquities; outside of that geographical and chronological sphere, their usefulness--and, accordingly, their use-tailed off rapidly. The stories have already been told of northern Europe's discovery of 
the 'third antiquity', that of their barbarian forebears, of the early moderns' fascination not only with ancient Egypt but with ancient Persia, Palmyra, and other near eastern cultures, and of the Italian rediscovery of the Etruscans. ${ }^{64}$ The students of these scholarly moments, and many others, were happily described by their contemporaries as antiquaries--Sweden even established a 'College of Antiquaries' (Antikvitetskollegium) to further its own nationalist approach to the ancient past--but their sources and their interests quickly diverged from the models of their classical counterparts, Varronian or otherwise. Outside of the classical world geography tended to be the primary framework in which antiquarian works were conceived, whether they were William Camden's chorographical magnum opus Britannia, Ole Worm's study of Danish megalithic remains, or Philipp Clüver's oft-reprinted textbook for the study of ancient Germany. ${ }^{65}$ Likewise, different methodologies and ways of approaching antiquarian material quickly developed in different national contexts. The English were fond of chorographies of counties containing everything from funeral monuments to natural philosophical observations; the Scots preferred wide-ranging, polemical works built upon the study of medieval manuscripts; and the Swedes combined the philological study of saga texts with archaeological investigation of material remains--to give only a few examples. ${ }^{66}$

These diverse approaches highlight the porous and uncertain boundaries of antiquarian studies. While some scholarship has worried over the point at which antiquarianism becomes history and vice-versa, one could just as easily ask the same question of antiquarianism and philology, or geography, or chronology. Fabricius effectively defined the latter two as Hilfswissenschaften of the antiquary, a land grab which seems not to have raised any significant protest at the time, and Morhof had no 
doubts about the interpenetration of antiquarianism and philology, writing that 'we annex antiquaries to critics, because amongst these things they are most closely related: by which I mean they labour at the same mine' ${ }^{67}$ In many cases, to strive for a clear definition of one treatise as antiquarianism or another manuscript as chronology risks falling into linguistic hair-splitting rather than clarifying the issue.

In sum, the vineyard in which antiquaries laboured was not a tidy one. Its boundaries shifted, its methods were multiple and eclectic, and it obeyed no unifying laws. It would be a mistake, however, to assume from this that we can learn nothing from the works of Fabricius, Spon, and their contemporaries. On the contrary: understanding what antiquaries thought their field was at its high tide mark allows us to significantly reassess the nature of antiquarian scholarship and the place of the antiquary within late humanist learning.

\section{Some Propositions for Reassessing Antiquarianism}

To reassess the field through any monolithic narrative--teleological or otherwise--would lead only to a partial and skewed picture. As has been repeatedly emphasized in recent publications, what is now known is no more than a crude map of one small section of the vast continent of antiquarian writing. ${ }^{68}$ Instead, I propose that we can recover, not a single narrative, but a set of allied practices and assumptions from the study of individual antiquaries--practices and assumptions which can then serve as a basis for more general hypotheses. In the present instance, three key players in European antiquarianism during the seventeenth and eighteenth centuries--Ole Worm, John Aubrey, and Thomas Innes-- 
can provide examples of thought and practice which allow for larger conclusions about the nature of antiquarianism in its golden age.

Who were these three scholars and why are they appropriate examples? The Dane Ole Worm (1588-1654) was the most influential representative of the several generations of antiquaries who shaped understandings of the Scandinavian past from the beginning of the seventeenth century through the mid-eighteenth century. ${ }^{69}$ Born into a mercantile family in Aarhus, Worm followed a traditional humanist trajectory, matriculating first at the University of Marburg, but subsequently undertaking an academic pilgrimage through Germany, Switzerland, Italy, France, the Low Countries, and England before returning to Denmark in 1613. Two years later, he was appointed Professor of Greek at the University of Copenhagen and subsequently became Professor of Medicine in the same institution. ${ }^{70}$

Worm had been fascinated by antiquities, particularly Runic inscriptions, from an early date, corresponding with the poet Bertil Knudsen Aquilonius on the subject as early as $1619 .^{71}$ By 1622 this interest had transformed into a government-sponsored project to record surviving runestones in the Danish territories, with a royal letter being sent out in that year ordering the Norwegian bishops to answer a series of questions by Worm concerning antiquities within their dioceses. ${ }^{72}$ This was followed in 1626 by Fasti Danici, a treatise on Runic calendars, in 1636 by Runir, seu Danica literatura antiquissima, a full-length treatise on Runic and the Norse language, and in 1643 by his magnum opus Danicorum monumentorum libri sex, as well as other, smaller works. ${ }^{73}$ In the Monumenta Danica, Worm not only surveyed the vast number of runestones which his earlier enquiries had uncovered, but also developed a stadial theory of ancient burial practices and other customs centred on stone monuments, providing ample grist for the mills of 
later antiquaries studying the prehistory of northern Europe ${ }^{74}$ His publication of what was, at the time, revelatory new material ensured his relevance in antiquarian circles well into the eighteenth century.

One of the many scholars who made use of Worm's studies of Scandinavian material culture was the English antiquary John Aubrey (1626-1697) $\cdot{ }^{75}$ Like Worm, Aubrey had come to antiquarianism through other scholarly disciplines, particularly the natural philosophy and experimental science associated with the Royal Society, of which he was an early member. It was through the Society that he was first commissioned to survey the megalithic sites at Stonehenge and Avebury, a project which led him into a more comprehensive survey of prehistoric monuments in Britain, à la Worm, as well as studies of folk customs, toponyms, architecture, and manuscripts, among others. Aubrey has frequently been painted as an archaeologist avant la lettre, but his investigations of stone circles and Roman remains, preserved in his Monumenta Britannica, must be read in tandem with his other scholarly works ${ }^{76}$ Doing so, grounds him both in the specific historical moment of later seventeenth-century England and in the polymathic culture of antiquarianism during the same period.

Although geographically propinqitous, Scotland had developed an antiquarian tradition very different from that of England. Thomas Innes (1662-1744) exemplifies the Scottish tradition of intensive study of the middle ages primarily through manuscript sources. ${ }^{77}$ Part of Scotland's beleaguered Catholic community, he was educated in Paris at the Scots College and the Collège de Navarre, where he came under the influence of the Jansenism of Port Royal and the diplomatic methods of Jean Mabillon and the Maurists. ${ }^{78}$ His first antiquarian scholarship came in the form of cataloguing pre- 
Reformation Scottish ecclesiastical documents preserved in the Scots College and of participating in the celebrated 'verification' there of a fourteenth-century charter proving the legitimacy of Robert III. ${ }^{79}$ Later in his life, after extended periods of service on the Scottish mission in which he extensively explored local archives while traveling under an alias, he produced three major tracts: the first on the early secular history of Scotland, the second on its religious history, and the third a year-by-year chronology of Scottish history from the eleventh century to the Reformation.$^{80}$ The first of these works, his Critical Essay on the Ancient Inhabitants of North Britain, defined its field of study for the subsequent two centuries.

Read together, the careers and works of these three scholars present different aspects of a shared tradition, an understanding of whose contours can help us reach a better understanding of antiquarianism across Europe. While the conclusions reached here are contingent and subject to subsequent revision or disproof, collectively they offer a way of reconceptualizing the discipline through the comparative study of its practitioners. In doing so, they also offer an important corrective to some of the myths which have sprung up about antiquarianism since its rehabilitation as an object for serious scholarly study.

\section{The work of the antiquary exists across multiple disciplines.}

The corollary of the early modern linguistic usage which focuses on the antiquary rather than on his or her discipline is that antiquaries may accomplish their work in other disciplines, e.g., no early modern seems to have doubted the applicability of the title 
regularly given to that 'Famous and Learned Antiquary, [John] Selden' but Selden's works fall within a variety of disciplines, chiefly law and philology ${ }^{81}$ The antiquary may engage in his research, but its result may not be antiquarianism. This distinction does not undermine antiquarianism, but rather opens up the possibility, if not the necessity, of paying closer attention to its intersections with other types of scholarship. Philology, history, literature, and art history, whose shared debatable lands with antiquarianism have already attracted comment, obviously overlap with antiquarian studies, but so are chronology, geography, theology, architecture, and art, among others. Equally, antiquaries could draw upon the methodological tool boxes of multiple disciplines in their own work. The nature of the antiquarian project--recovering and interpreting the traces of the past--meant that it intersected with a great many early modern preoccupations: calculating the age of the world, understanding the changing shape and character of that world, making sense of the cultures depicted in the Hebrew and Christian scriptures, restoring architecture to its classical 'purity', and creating art which reflected the (neo)classical ideals of its producers and consumers, amongst many others.

The disciplinarily porous nature of antiquarianism is evident in the works of the three antiquaries under consideration here. Ole Worm's Fasti Danici, for example, was essentially a work of technical chronology, interpreting and making use of a fourteenthcentury Runic computus which he had previously discovered and transcribed--a project not so different from the chronological work of scholars like Joseph Justus Scaliger. ${ }^{82}$ It fed, however, into a nexus of antiquarian scholarship on the Runic alphabet and Old Norse literature which also included philological elements, such as his exegesis of the Icelandic Rune Poem, and more obviously antiquarian projects such as his catalogue of 
runestones and accompanying study of the uses of megalithic and runic monuments. ${ }^{83}$ To attempt to define some parts of Worm's larger project as 'antiquarian' and others as 'chronological' or 'philological' is to misread the essentially hybrid nature of late humanist scholarship; the scholarly techniques which were often associated with the label 'antiquary' could be put to use in a wide variety of disciplinary spheres.

\section{In theory antiquaries had almost unlimited scope, but in practice they clustered} around certain shared fascinations.

As has been demonstrated, the scope for antiquarian pursuits was dizzyingly wide; antiquarian treatises can be found on topics as vastly divergent as the comparative history of wigs and the origins of blessing after a sneeze ${ }^{84}$ However, while some subjects attracted one or two books and a scattering of references further afield, others bulked so large that they developed their own bibliographies, systems of reference, and subdisciplinary cultures. A few of these, such as the history of religion, have an immediate relevance in the modern era and have received sustained attention accordingly, but most have been largely overlooked.$^{85}$ Chief amongst these was the collection and study of coins, which generated a vast, but largely unmapped, literature during the early modern period and could boast of two sub-disciplinary bibliographies by the early eighteenth century--Banduri's Numismata referred to above and Philippe Labbe's earlier Bibliotheca bibliothecarum (1672)--as well as innumerable handbooks, guides, and specialized studies. ${ }^{86}$ Alongside numismatics, epigraphy was studied intensively from the fifteenth century onwards, but while William Stenhouse has provided a masterful account of the 
earlier history of epigraphic studies, the centuries between his work and the Corpus Inscriptionum Latinarum remain poorly understood.$^{87}$ Likewise, the many antiquarian studies of ancient social history which were produced--discussing dining customs, clothing, social structures, the society which could be observed behind Roman law codes, and many similar topics--have received surprisingly little attention. While the antiquaries' forays into the history of private life might at least be calculated to attract modern enthusiasm, other enduring antiquarian fascinations remain neglected due to their rebarbative subject matter. Antiquaries in the German lands were particularly fascinated by genealogies, both ascending and descending, writing works on the standards of proof required for them to be admissible in a legal context as well as weighty folios of exquisitely printed charts depicting the ancestors and descendants of the Holy Roman Empire's many petty sovereigns. ${ }^{88}$ When Johann Hübner produced his Bibliotheca Genealogica in 1729, he was able to reference well over six hundred works on the topic; many more were written during the flowering of the genre later in the eighteenth century. ${ }^{89}$

These areas of emphasis over time developed their own gravitational pulls, encouraging still further contributions to already well-established fields, even by scholars whose principal interests lay elsewhere. John Aubrey, for example, recorded Roman epigraphy with the explicit intent of adding to the corpus already produced by William Camden, and also took note of the classical coins discovered by one of his more erudite neighbours;,Ole Worm's runestone catalogue was almost inevitably situated within the contexts of earlier classical epigraphy; Innes, though himself not genealogically-inclined, was drafted in as a resident expert by Scots abroad seeking genealogical material for 
pragmatic purposes. ${ }^{90}$ Obvious enough is that what the early moderns found interesting or important is not necessarily what we do, but it is nonetheless worth recalling in this context. To better understand antiquarianism, we must better understand the obsessions of scholars across Europe with coins, genealogies, Roman lamps, and a host of other subjects and objects.

\section{The antiquary was never limited to material culture alone.}

This is one of the more persistent myths surrounding early modern antiquaries, fueled by the ground-breaking studies of antiquarian archaeology published in recent decades. ${ }^{91}$ While the recovery (potentially excavation) and interpretation of artefacts was well within the antiquary's purview, texts were also used, often to the exclusion of material remains. Indeed, one of the most significant contributions of antiquarianism to early modern scholarship was its study of manuscripts and their methods of production, and of the past scholarship which they encoded. Emerging from the study of medieval charters and saints' lives, diplomatic established itself as a distinct branch of antiquarianism over the course of a several decades' long debate over the methods of identifying forgeries..$^{92}$ The 1675 volume of the Acta Sanctorum contained an essay 'Propylaeum antiquarium' by the Bollandist Daniel Papebroch which laid out a set of indicators by which a document could be identified as spurious. ${ }^{93}$ These were essentially markers of anachronism and Papebroch's essay was part of a longer philological tradition which stretched back to Lorenzo Valla's demolition of the Donation of Constantine in the

fifteenth century, but it engendered something new. ${ }^{94}$ In 1681 the Maurist scholar Jean 
Mabillon published his seminal De re diplomatica, in part as a defence against what he saw as the hypercritical approach of Papebroch. ${ }^{95}$ Mabillon's counter, however, was an appeal not simply to philological tools but to the materiality of the documents themselves as testaments of their authenticity or lack thereof, comparable to the more basic but conceptually analogous attempt by John Aubrey to develop a system for dating undated medieval documents by comparison of letterforms. ${ }^{96}$ While such approaches were undoubtedly more 'material' than a philology which considered only text qua text, they were not compartmentalised from more traditional philological scholarship; rather they added a further layer of meaning which a philologist-antiquary could recover from any given manuscript. One could also state with equal truthfulness that 'the philologist was never limited to texts alone'; the commentaries which accompanied so many early modern editions of classical authors roamed widely across the scholarly landscape, taking in antiquarian topics as well as purely philological ones.$^{97}$ Instead, the two disciplines interpenetrated to an extent that in many contexts makes any attempted compartmentalization meaningless.

The problem of identifying forgeries--part of larger late seventeenth-century concerns over Pyrrhonism and fides historica--continued to be raised by antiquaries such as Barthélémy Germon and George Hickes, but the methods established by Mabillon were there to stay. ${ }^{98}$ In France, Bernard de Montfaucon revolutionized the study of Greek manuscripts in imitation of what Mabillon had done for Latin; in Italy the De re diplomatica influenced a generation of antiquaries, most notably Scipione Maffei; yet the new techniques of diplomatic found particularly fertile ground in Scotland. ${ }^{99}$ Scotland was having its own moment of Pyrrhonist crisis at the end of the seventeenth century as 
older Renaissance narratives of its ancient history were systematically demolished and Mabillon's methods offered tools with which to retrench and rebuild. James Anderson and Thomas Ruddiman's 1739 Thesaurus--designed on the model of the De re diplomatica--aimed to do just that, but was attuned to antiquarian, not philological, issues and concerns.$^{100}$ Likewise, Thomas Innes participated in Scotland's Mabillonesque activities, publishing numerous manuscript sources from Britain and France as an appendix to his Critical Essay and providing accounts of their physical appearances and institutional histories. ${ }^{101}$

Antiquaries also made use of oral traditions as well as texts and artefacts. Although often denigrated--particularly when derived from the lower social classes-orality remained a key aspect of many antiquarian and historical narratives. ${ }^{102}$ Aubrey's Remaines of Gentilisme, for example, was built upon the hypothesis that oral folklore in the British Isles could reflect ancient pagan custom and, though undeniably an antiquarian text, the book was based almost exclusively on oral and textual research. ${ }^{103}$ Such texts highlight the danger of assuming antiquarianism limited itself to something approaching modern archaeology; instead, its remit was far broader and could include a heterogenous array of sources including, but not limited to, sites, artefacts, texts, and oral traditions.

\section{The study of antiquities stretched across Europe, but its practices and emphases could vary significantly between regions.}


The antiquary was an international figure whose reach was coterminous with that of humanist scholarship, but the particularities of individual cultural regions led to antiquarian studies in one part of Europe often looking very different from those in another. It would be dangerous, then, to generalize too much about the development of a pan-European antiquarianism without equal attention being paid to its national or local peculiarities. Equally, it misses an important part of the discipline to assume that certain characteristic national antiquarianisms--such as the English obsession with county history--represent the whole of the field, rather than one small part.

Indeed, many misconceptions concerning antiquarianism have stemmed from reading the incredibly vibrant and complex English tradition as representative of the European whole. Focusing from an early date on chorographically structured research, English antiquarianism was defined by the Britannia of William Camden and resulted in an astonishingly large number of county and local histories from the late sixteenth through the early twentieth century. ${ }^{104}$ Aubrey was no exception. His two county histories--of Wiltshire and Surrey--were representative examples of the English tradition; his fascination with medieval architecture and with the specificities of place was very much in keeping with such friends and contemporaries as William Dugdale, William Somner, and Anthony Wood. ${ }^{105}$

But this was only one of many regional traditions. Ole Worm, by contrast, was a key player in a far more adversarial antiquarian culture which had grown up in Sweden and Denmark during the latter part of the sixteenth century and survived well into the eighteenth. ${ }^{106}$ Unwilling to share out the culture capital of Old Norse literature, the two nations competed viciously for their right to an authentic, 'Gothic' heritage, with Worm's 
publications on the Runic alphabet representing a master stroke for the Danish side. Later, as Sweden arose from the Thirty Years' War as a newly-minted great power, the tables were turned by a tendentious, but polymathic, group of antiquaries based in the University of Uppsala; it culminated in a baroque antiquarian tradition, which read sagas as manifestations of a supposed ancient Gothic culture and, in turn, interpreted this Gothic heritage as the natural product of the Swedish landscape, an angle radically different from that pursued by English county historians. ${ }^{107}$

Again, in Scotland there were different emphases and different questions demanding answers. A pre-Reformation power grab by Scottish ecclesiastics seeking control of Irish monasteries on the continent had led to a centuries-long controversy between scholars from the two countries over the extent and definition of medieval 'Scotia', a debate in which Innes could not help becoming involved. ${ }^{108}$ At the same time, as older sixteenth-century humanist narratives of early Scottish history came increasingly under fire, Scottish antiquaries at the end of the seventeenth and beginning of the eighteenth centuries tended to focus on the country's early medieval past and the ramifications that past had upon present political and religious structures. ${ }^{109}$ In the Scottish context, antiquarianism fed directly into contemporary debates over the nature of royal power and the structure of a Scottish church. ${ }^{110}$

In sum, then, the presence of something recognizable as antiquarianism across and beyond Europe should not blind us to national, regional, or local particularity. Like any other groups of scholars, antiquaries responded to the immediate concerns of the culture in which they lived and built upon the methods and forms of scholarship most 
familiar to them. That could take place at a continental level, but could also occur on a far smaller--though by no means less significant--scale.

\section{Antiquaries, in making truth claims about the past, participated in an inherently confessional activity.}

In an intellectual culture dominated by multiple Christian denominations, all of whom made exclusive claims for their correct recovery and interpretation of past religious practices, it was inevitable that antiquaries should be subjected to confessional pressures. Most obvious are those antiquaries who themselves worked to further the truth claims of their respective confessions, with the Catholic Cesare Baronio and his Protestant opponent Isaac Casaubon standing out as leading figures in the philological-antiquarian debates over the nature of the early church which dominated post-Reformation Europe. ${ }^{111}$ But Baronio and Casaubon were only two particularly successful examples of a common type, 'the True Church Antiquary', as Thomas Fuller called it, who studied sacred history from an antiquarian viewpoint. ${ }^{112}$ Many of Thomas Innes's works fall into this category, ranging from his treatise on the ancient liturgical practice of Scotland to his vast Civil and Ecclesiastical History, both of which were written explicitly with the aim of proving the validity of Scottish Catholic tradition. ${ }^{113}$

In some Protestant states, the mere act of being an antiquary could arouse suspicions of Catholicism. When William Dugdale published his Monasticon (1655-1673) he faced deep hostility on the part of at least some of his Protestant readers on the grounds that 'it was published purposely to promote popery'. ${ }^{114}$ The Oxford antiquary Anthony Wood was widely--and not entirely unreasonably--'lookt upon as a Papist' and 
even John Aubrey, whose actual religious beliefs were far more heterodox and who memorably wrote 'fough the Cassock stinkes', was at times accused of Catholicism because of his fascination with the past. ${ }^{115}$ While not every antiquary wrote for confessional purposes, nor was every antiquary branded with a confessional stamp for their activities, the link between the excavation of the past and religious polemic remained strong well into the nineteenth century.

\section{Antiquarianism never died, but the term 'antiquary' underwent a semantic shift.}

This point has already been made, particularly by Miller, but bears repeating. ${ }^{116}$ As 'antiquary' and 'antiquarianism' became terms of abuse, respectable scholars began to dissociate themselves from the terms--an act made both easier and more necessary by the simultaneous development of many of the modern scholarly disciplines--but the new generation's wholesale exit from the creaking hulk of antiquarianism for sleeker barques such as Alterthumswissenschaft, Kunsthistorie, and anthropology did not necessarily

imply a dramatic break from the ways of thought and scholarship of their predecessors. ${ }^{117}$ This moment, which seems to have extended from the latter part of the eighteenth century well into the nineteenth, remains one of the least studied, but most important, periods in the history of European antiquarianism and offers the possibility for much fruitful reconsideration of the origins of the modern academic disciplines. ${ }^{118}$ Likewise, the rump of scholars who stubbornly clung to the label 'antiquary' long after it ceased to be fashionable require further examination. ${ }^{119}$ If a self-professed antiquary could write in the 
1850 s that 'the science of the real antiquary is not of a narrow and limited character. To him, every relic which he picks up or secures, is pregnant with instruction, as bearing upon the history or the social life or habits of some past age', to what extent were this generation of nineteenth-century antiquaries both inheritors of the older tradition and ancestors of modern scholarship? ${ }^{120}$ Crucially, what was their real, rather than rhetorical, relation to their professionalised cousins?

This rapid tour through the works of Worm, Aubrey, and Innes has suggested a number of revisions to how we understand antiquarianism: it existed across other disciplines, it often focused on a comparatively small set of specific sub-fields (numismatics, epigraphy, genealogy, and others), it drew upon a heterogenous sourcebase (not just material culture), it could vary widely between regions, and its practices did not fade away but were rather renamed and fragmented with the rise of the modern disciplines in the nineteenth century. If these conclusions appear vague or ambiguous, it is not by accident. The danger lies the other way: in 'splitting' rather than 'lumping'; in requiring antiquarianism to conform to modern assumptions about what constitutes a coherent field of scholarly study. Instead, antiquarianism should be understood as something inherently amorphous, recognizable but fluid, and freely shading into the practices of other disciplines. To accept this more elastic definition is to accept the fundamental elasticity, ambiguity, and polymathic nature of early modern scholarship.

\section{Interpreting Antiquarianism}


If this is the scope of antiquarianism as we currently understand it, where might we proceed from here? This section presents a number of possibilities, ranging from structural and methodological issues which remain to be clarified to ways in which antiquarian thought can be more sensitively mapped and understood. In such a large and untilled field these are only some--albeit perhaps the most pressing--of the many possibilities for future research. It is hoped, however, that these suggestions will provide a starting point from which new histories of antiquarianism might be developed.

If the scholarly consensus now rejects a sharp break between pre-modern antiquarianism and modern scholarly practices, the link between the two remains understudied. As mentioned above, a major desideratum in antiquarian studies is an examination of the ways in which antiquarianism became history, art history, sociology, anthropology, and so forth in the eighteenth, nineteenth, and twentieth centuries. How was the gap bridged between, for example, Innes's study of early modern Scotland and the study of the Victorian historian William Forbes Skene, often seen as the founder of modern medieval Scottish studies? ${ }^{121}$ Equally, what path can be traced between Ole Worm and the great Scandinavian scholars of the nineteenth century or between John Aubrey and his appreciative successor Stuart Piggott in the twentieth? ${ }^{122}$ Future scholarship on antiquarianism could beneficially ask questions such as: what narrative can be traced for antiquarianism from the mid-eighteenth to the mid-nineteenth centuries? How did antiquarianism interact with the genesis of the modern disciplines? Asking these questions can help us better understand what, precisely, antiquarianism was, how it relates to modern scholarly practice, and how it was, nonetheless, something different and a product of its own time. 
Recent scholarship has forced us to rethink the supposition that there is an end point for antiquarianism. It has also made us question its natural link to history. An important issue for future research will be the debatable border between antiquarianism and philology, literature, and art history as discussed elsewhere in this article. Where does one begin and the other end? How, if at all, was that conceptualized by the early moderns themselves? And to what extent should we take this distinction into account in our own study of early modern scholars? It may be that maintaining any such distinction is more unhelpful than not, and we would do better to think of these practices as inextricably linked: different methods with a shared aim of recovering the past.

Another question to consider is how future, more focused, studies will organize genealogies of antiquarian thought. The predominant method, particularly in Anglophone and Scandinavian scholarship, has been to look at national schools of antiquarianism, as in the work of Graham Parry, Angus Vine, and Ole Klindt-Jensen, among others, but this is not the only option available. ${ }^{123}$ Sawilla's work on the Bollandists centers on an international scholarly community; Schnapp's studies of archaeological practice have traced a single type of learning across national and chronological boundaries. There remains much potential, however, for writing subject-specific genealogies of antiquarian thought, analogous to Stenhouse's work on the study of inscriptions, as well as intellectual biographies of individual antiquaries which pay due attention to the longer scholarly history encoded in their own sources. Despite being regularly named in this regard, even Gibbon awaits a biographer who will systematically place his thought within the context of his antiquarian, rather than historical, sources and read that as part of larger trends in European antiquarian thought. ${ }^{124}$ 
Understanding the scope, characteristics, and evolution of a past scholarly practice is one thing; forging a nuanced interpretation, however, is dependent on understanding the goals and preconceptions, the stresses and ideals, of antiquarian texts and their creators. When Anthony Grafton wrote in a review of E. J. Kenney's 1974 Classical Text that 'if we are ever to make progress in understanding the history of scholarship, it will be by finding out what earlier scholarship was, not by denouncing it for being different from ours' he was responding, not only to Kenney, but to a long tradition of essentially internalist criticism which judged past scholarly works by how far they 'got it right'. ${ }^{125}$ The history of scholarship has come a long way in the past three decades, but Grafton's cautionary note still needs to be sounded. If we are to make sense of antiquaries and their work, we must move beyond a right/wrong, presentist dichotomy and look at them within the context of their times. Likewise, a better understanding of antiquarianism requires us to jettison the intellectual narrative which Christopher Wood has described 'as a progressive illumination of darkness obstructed only by fools or knaves'. ${ }^{126}$ While there was a recognizable antiquarian tradition and later scholars built upon the achievements of those who came before, reducing the field as a whole to a forward-moving, teleological arc strips it of its most intriguing aspects. Such a model has no room for the forged manuscripts of Annius of Viterbo, the Baroque nationalism of Olof Rudbeck, or the Enlightened dream-theology of William Stukeley; but neglecting antiquaries such as these gives a pale and distorted impression of the field. ${ }^{127}$

Some of the most innovative research into new ways of thinking which go beyond the right-wrong binary has been by Christopher Wood. ${ }^{128}$ Discussing learned credulity-the distressing habit of early modern scholars to believe what seems to us patently 
absurd--Wood has rehearsed three explanations, each of which involve the mixing of categories which are now distinct, whether that be the antiquarian and the aesthetic, the antiquarian and the propagandistic, or the antiquarian and the mythic. ${ }^{129}$ To these explanations, Wood has added another: the simultaneous existence of 'two models of the production of artifacts', one substitutional, in which a modern artefact can stand in and replace a hypothetical ancient exemplar, and one archaeological, in which each artefact is 'an inalienable trace of its originary point'. ${ }^{130}$ In Wood's model, 'credulity' in early modern scholarship is really the intersection of multiple competing, or contradictory, ways of thinking about the past. Exploring how this model plays out in specific antiquarian contexts would be of great benefit to the field as a whole.

If Wood's theories of credulity offer fresh ways of thinking about antiquarianism, emotion does as well. The history of emotions now possesses a formidable body of scholarship in its own right, but this has tended not to focus on scholarly emotion. Yet even a slight acquaintance with antiquarian texts reveals their emotive qualities. William Somner, in his 1640 Antiquities of Canterbury, gave two reasons for composing a treatise on the cathedral city's history. On the one hand, the preservation and memorialization of the past was clearly an absolute good. ${ }^{131}$ This was not Somner's only reason, however-nor even necessarily his principle one. 'My thoughts and affections', he wrote, 'ever much inclined to the search and study of Antiquities'; ${ }^{132}$ elsewhere he wrote even more strongly of 'the Authors love to Antiquities' ${ }^{133}$ Somner was by no means the only antiquary to phrase his motivations this way. James Wright, in his 1684 History and Antiquities of Rutland, claimed that he had 'collected many years ago something of this nature for my own private satisfaction', adding that the subject itself was naturally 'facile 
and delightsome'. ${ }^{134}$ John Selden, in his 1610 Janus Anglorum, wrote that 'I do own for my self, what Seneca the Declaimer saith, that I take pleasure in going back to Studies of Antiquity' and William Lambarde, in his 1576 Perambulation of Kent, observed, almost as a matter of course, that 'many men are much delighted with' the study of antiquities. ${ }^{135}$ Even the ordinarily po-faced Robert Plot wrote that he had at first undertaken his Natural History of Oxfordshire 'for my own pleasure, the subject of it being so pleasant, and of so great variety' ${ }^{136}$

These are all English texts and further research into the presence or absence of this kind of language elsewhere in Europe is imperative, but within this English context the consistency with which this rhetoric of love, pleasure, satisfaction, and delight appears is striking. Often this was conceived in terms of a 'natural genius' for the subject: Nicola Francesco Haym, for example, wrote in 1719 that "what principally inclined me to undertake [a study of ancient numismatics], was a natural Genius to it, which grew up with me from my Infancy'; Thomas Hearne, writing a biography of John Leland, the Tudor antiquary, in 1711 noted that 'when he was a Young Man . . . he had, through the strength of his Natural Genius, made ample Collections concerning the History and Antiquities of [Oxford] and of other Places thereabouts . . ${ }^{137}$ At times this 'natural genius' went beyond pleasure into the realm of obsession, as when the author of the anonymous 'Life of Mr. Camden' prefixed to the 1701 abridgement of his Britannia explained that Camden 'was put upon a search after Antiquities by powerful Motives, such as his own natural Genius ... When a School-Master he would fain have dismiss'd his Curiosity, but could not ...' 138 
Perhaps the most eloquent plea of this nature was made by William Burton in his 1622 Description of Leicestershire:

yet was I drawne to this Studie of Antiquities by a naturall Genius, and as those two learned writers Georgius Brunius and Hieronimus Henninges (the one the Author of Theatrum Vrbium, the other of Theatrum Genealogicum) doe say of themselves, that though by profession and calling they were Divines, yet being drawne by a naturall instinct, the one to the loue of Pictures, Perspectiues, Mappes, and other Geographicall delights; the other to the studie of Genealogies, that therefore no man should lay any imputation upon them, for those their labours, sith that (say they) ... many Fathers of the Church, did delight themselues with humane learning ... [t]he like may I say for my selfe, I gaue way in some sort to my owne desire, choosing rather to recreate my selfe in this kinde, then either to be misimployed, or altogether idle $\ldots{ }^{139}$

Not only do Burton's reflections point toward a much older pedigree for the rhetoric of natural genius and antiquarian emotion; they should encourage us to rethink how we understand the motivations of antiquaries. Pleasure and desire intermingled are never far from the surface in any of these texts, and it would not be reaching too far to entertain the idea of an emotive theorization of antiquarianism, one in which the desire for knowledge of a thing leads into the pleasure of understanding. The parallel with the desire of the collector is obvious, though we should not reduce the desire for knowledge into a form of collecting. Equally evident is the rhetoric of calling and 'natural genius' echoing, indeed 
borrowing from, the rhetoric of religious vocation; for many antiquaries the call of their work was conceptualized in terms as strong as any priest or minister's call to the cloth. To ignore these narratives is to discard an important part of the antiquaries' self-identity.

\section{Conclusion}

This paper has attempted to chart a series of new routes into early modern antiquarianism. In answering the question 'what is antiquarianism?', it has returned to contemporary actors' categories and placed emphasis not upon the anachronistic concept of antiquarianism, but upon the early modern concept of the antiquary. Antiquaries studying the classical world in the seventeenth and eighteenth centuries had a choice of conceptual frameworks for their scholarship. Some appropriated a Varronian model, which divided their field of research by subject, into human-divine, public-private, and so forth. Others preferred Jacques Spon's object-based divisions. And by the early nineteenth century an eclectic mixture had become the norm, defining the antiquary's remit partly by subject of study. partly by object studied. Beyond the study of the classical world, however, national and geographical divisions reigned supreme, and within individual national antiquarianisms there existed a vast range of methodological approaches and emphases. The remit of early modern antiquarian studies was expansive but porous; it is no easy matter to ask where history or philology or chronology ends and antiquarianism begins.

To ask this last question, however, is to misunderstand the nature of the antiquary, whose work could extend across, and underpin, multiple disciplines. While the antiquary performed his or her research, the result may not be defined as antiquarianism but rather 
chronology, geography, philology, art history, or something else entirely. This was a natural by-product of the potentially vast reach of antiquarianism, but in practice some subjects attracted more curiosity than others and this paper has also argued for the importance of attending to antiquaries' own fascinations: coins, epigraphy, ancient private life, genealogies, and other now neglected corners and cubby-holes of the field. Nor was antiquarianism limited solely to the study of artefacts; the study of manuscripts had always been an integral part of it, and the modern science of diplomatic has its origins in the antiquarian disputes of the seventeenth century.

Antiquarian scholarship responded to diverse needs and flowered in diverse conditions across early modern Europe. Unsurprisingly, its practices were equally diverse and varied widely from region to region, country to country. In understanding the discipline as a whole, then, no single national study can hope to fully recover its diversity; as new scholarly traditions are investigated, new forms of antiquarianism will emerge. This applies not only in space, but in time. At the end of the end of the eighteenth and the beginning of the nineteenth centuries, 'antiquarianism' began to undergo a profound semantic shift, becoming a term of abuse for poor scholarship or a love of pointless detail rather than for the multi-disciplinary study of the past. This should not, however, lead us into a belief that antiquarianism decayed or died. Instead, antiquarian practices assumed new labels as the modern historical and social sciences.

This article has also argued that as well as understanding the scope and practices of early modern antiquaries, it is imperative to pursue new ways of interpreting their works. It is necessary to move away from the teleological narrative of enlightened progress that still too often dominates histories of scholarship and explore instead the 
mental world of the antiquaries on their own terms. Christopher Wood's model of learned credulity as the intersection of multiple, contradictory ways of thinking offers one way into this. Increased attention to antiquarian emotional rhetoric offers another. What can the claims of devotion and vocation made by many antiquaries tell us about their own self-identity and the identity and practice of their scholarship?

Antiquaries have a history of suffering from the misapprehensions of others: they were pedantic, or foolish, or absurd, or, more recently, they were systematic, or concerned only with material artefacts, or essentially uncritical. The present paper has tried to lend its weight to that of a growing mass of literature which pushes against these misapprehensions, revealing instead a vision of the antiquary as a dynamic, interdisciplinary, questioning scholar whose work stretched across many disciplines and fields of enquiry and whose scholarship lay at the centre of humanist and enlightenment projects to recover and understand the human past. 'The History of Antiquarian Studies' has still not been written, but we are now in the position to consider what questions we might want to ask.

I am grateful to the British Academy for funding the research fellowship during which this project was undertaken and would like to thank Anthony Ossa-Richardson, Dawn Hollis, and the two anonymous readers for their invaluable comments and corrections. 1 'Arnold's Lectures on History', Blackwood's Edinburgh Magazine 53 (1843), 146. Quoted and discussed in Kelly Eileen Battles, The Antiquarian Impulse: History, Affect, and Material Culture in Eighteenth- and Nineteenth-Century British Literature (Michigan State University Ph.D. Thesis, 2008), 15. 
${ }^{2}$ Arnaldo Momigliano, 'Ancient History and the Antiquarian', Journal of the Warburg and Courtauld Institutes 13 (1950), 311. Cf. also the summary and analysis by Peter N. Miller, 'Momigliano, Antiquarianism, and the Cultural Sciences', in Momigliano and Antiquarianism: Foundations of the Modern Cultural Sciences, ed. Peter N. Miller (Toronto, 2007), 8-19.

${ }^{3}$ Arnaldo Momigliano, 'The Rise of Antiquarian Research', in Classical Foundations of Modern Historiography (Berkeley, 1990), 54. See Miller, ed., Momigliano and Antiquarianism, 21-22.

${ }^{4}$ Momigliano, 'Rise of Antiquarian Research', 57-58.

${ }^{5}$ Momigliano, 'Rise of Antiquarian Research', 58; Momigliano, 'Ancient History and the Antiquarian', 286.

${ }^{6}$ See Peter N. Miller, Peiresc's Europe: Learning and Virtue in the Seventeenth Century (New Haven and London, 2000) and Peiresc's Mediterranean World (Cambridge, Mass., and London, 2015).

${ }^{7}$ Peter N. Miller, 'Major Trends in European Antiquarianism, Petrarch to Peiresc', in The Oxford History of Historical Writing, Volume 3: 1400-1800, ed. Jose Rabasa, et al.

(Oxford, 2012), 244-260; ‘A Tentative Morphology of European Antiquarianism, 15002000', in World Antiquarianism: Comparative Perspectives, ed. Alain Schnapp, et al. (Los Angeles, 2013), 67-87.

${ }^{8} \mathrm{Cf}$. also the argument in Miller, ed., Momigliano and Antiquarianism.

${ }^{9}$ Karl Bernhard Stark, Systematik und Geschichte der Archäologie der Kunst (Leipzig, 1880), the first volume in a projected but never completed Handbuch der Archäologie der Kunst. For Stark's importance in the genealogy of antiquarian studies see Peter N. Miller, 'Writing Antiquarianism: Prolegomenon to a History', in Antiquarianism and Intellectual Life in Europe and China, 1500-1800, ed. Peter N. Miller and François Louis (Ann Arbor, 2012), 28-47.

${ }^{10}$ T. J. Cornell, 'Ancient History and the Antiquarian Revisited: Some Thoughts on Reading Momigliano's Classical Foundations', in Ancient History and the Antiquarian: Essays in Memory of Arnaldo Momigliano, ed. M. H. Crawford and C. R. Ligota (London, 1995), 7. 
${ }^{11}$ Cornell, 'Ancient History and the Antiquarian Revisited', 6.

${ }^{12}$ Arnaldo Momigliano, 'Gibbon's Contribution to Historical Method', Historia 2 (1954), 450-463.

${ }^{13}$ Anthony Grafton, What was History? (Cambridge, 2007), 190-192.

${ }^{14}$ See, for one example amongst many, Anthony Grafton, 'A Sketch Map of a Lost Continent: The Republic of Letters', Republics of Letters 1 (2009), 1-18.

${ }^{15}$ Anthony Grafton, 'Jean Hardouin: The Antiquary as Pariah', Journal of the Warburg and Courtauld Institutes 62 (1999), 243.

${ }^{16}$ Jan Marco Sawilla, Antiquarianismus, Hagiographie und Historie im 17. Jahrhundert: Zum Werk der Bollandisten (Tübingen, 2009), 260 and passim, quoting Jean Bodin, Oeuvres philosophiques, ed. and trans. Pierre Mesnard (Paris, 1951), 107a.

${ }^{17}$ Chantal Grell, L'histoire entre érudition et philosophie (Paris, 1993).

${ }^{18}$ Markus Völkel, „Pyrrhonismus historicus' und „fides historica': Die Entwicklung der deutschen historischen Methodologie unter dem Gesichtspunkt des historischen Skepsis (Frankfurt, 1987).

${ }^{19}$ Ingo Herklotz, Cassiano Dal Pozzo und die Archäologie des 17. Jahrhunderts (Munich, 1999).

${ }^{20}$ Ingo Herklotz, ‘Arnaldo Momigliano's 'Ancient History and the Antiquarian’: A Critical Review', in Momigliano and Antiquarianism, 127-153.

${ }^{21}$ Angus Vine, In Defiance of Time: Antiquarian Writing in Early Modern England (Oxford, 2010).

${ }^{22}$ Michael Drayton, Poly-Olbion (London, 1612) is discussed by Vine, Defiance of Time, 172-199. For Ferdinand von Fürstenberg, Prince-Bishop of Paderborn, Monumenta Paderbornensia (Paderborn, 1669), see Norbert Börste and Jörg Ernesti, eds., Ferdinand von Fürstenberg: Fürstbischof von Paderborn und Münster: Friedensfürst und guter Hirte (Paderborn, 2004).

${ }^{23}$ Thomas DaCosta Kaufmann, 'Antiquarianism, the History of Objects, and the History of Art before Winckelmann', Journal of the History of Ideas 62 (2001), 523-541.

${ }^{24}$ For the art historical background to Kaufmann's work see especially Francis Haskell, History and its Images: Art and the Interpretation of the Past (New Haven, 1993). 
${ }^{25}$ Kaufmann, 'History of Art before Winckelmann', passim, and see Joachim von Sandrart, L'Academia Todesca della Architectura, Scultura \& Pittura: oder Teutsche Academie der Edlen Bau-Bild- und Mahlerey-Künste, 3 vols. (Nuremberg, 1675-1679).

${ }^{26}$ Kaufmann, 'History of Art before Winckelmann', 541.

${ }^{27}$ Alain Schnapp, La Conquête du passé : Aux origines de l'archéologie (Paris, 1993).

See also Kelsey Jackson Williams, Review of World Antiquarianism, Erudition and the Republic of Letters 1 (2016), 107-111.

${ }^{28}$ Miller, ed., Momigliano and Antiquarianism, 52 (emphasis added); cf. Cornell, 'Ancient History and the Antiquarian Revisited', 1-14.

${ }^{29}$ Rebecca Gould, 'Antiquarianism as Genealogy: Arnaldo Momigliano's Method', History and Theory 53 (2014), 212-233.

${ }^{30}$ Gould, 'Antiquarianism as Genealogy', 215, citing Arnaldo Momigliano, Ottavo contributo alla storia (Rome, 1987), 23.

${ }^{31}$ Gould, 'Antiquarianism as Genealogy', 214.

${ }^{32}$ Gould, 'Antiquarianism as Genealogy', 233.

${ }^{33}$ Momigliano, 'Ancient History and the Antiquarian', 285.

${ }^{34}$ William Warburton, Letters from a Late Eminent Prelate to One of His Friends, $2^{\text {nd }}$ ed. (London, 1809), 264-265. Cf. OED. Warburton's juxtaposition of antiquarianism with 'true letters' may suggest that he had in mind Roman antiquaries such as Aulus Gellius and Macrobius who postdated the canonical greats of classical literature.

${ }^{35}$ Warburton, Letters, 428.

${ }^{36}$ Sir Walter Scott, Journal, ed. W. E. K. Anderson (Oxford, 1972), 441. Quoted and discussed in Battles, Antiquarian Impulse, 15.

${ }^{37}$ Isaac Casaubon, Epistolae, ed. Theodoor Jansson ab Almeloveen (Rotterdam, 1709), 489, '. . totius Reformationis pars integerrima est in Anglia. Ubi cum studio veritatis viget studium Antiquitatis'.

${ }^{38} \mathrm{Cf}$., as one example among many, a biography of the humanist scholar Beatus Rhenanus which associated studium antiquitatis with the study of 'sacred and profane Latin writers' (Johann Georg Groß, Urbis Basil. epitaphia et inscriptiones omnium temporum [Basel, 1622], 348). 
${ }^{39}$ For Camden see the discussion in John Considine, Dictionaries in Early Modern Europe (Cambridge, 2008), 169, and for Somner's epitaph see The History and Antiquities of the Cathedral Church of Rochester (London, 1723), 75-76.

${ }^{40}$ The editio princeps of Juvenal was printed in Rome by Ulrich Han about 1468-69 (Incunabula Short Title Catalogue, ij00625500; Gesamtkatalog der Wiegendrucke, M15754-6) and the editio princeps of Suetonius was also printed in Rome, by Johannes Philippus de Lignamine, in August 1470 (Incunabula Short Title Catalogue, is00815000; Gesamtkatalog der Wiegendrucke, M44220).

${ }^{41}$ Juvenal, Satires, VI. 452-454; Suetonius, Augustus, 86.

${ }^{42}$ Jerome, Epistolae, V. 2.

${ }^{43}$ Sawilla, Antiquarianismus, 238, citing Guido Panciroli, De magistratibus municipalibus (Venice, 1593), 183-198.

${ }^{44}$ Sawilla, Antiquarianismus, 238-239.

${ }^{45}$ Robert Estienne, Dictionarium, seu Latinae linguae thesaurus (Paris, 1531), not paginated ('qui est curieux de user de mots anciens').

${ }^{46}$ Momigliano, 'Rise of Antiquarian Research', 71; Johannes Rosinus, Thesaurus linguae Romanae \& Britannicae tam accurate congestus (London, 1578), not paginated.

${ }^{47}$ Encylcopédie, ou dictionnaire raisonné des sciences, des artes et des métiers, 28 vols. (Paris, 1751-1772), i. 515. « une personne qui s'occupe de la recherche \& de l'étude des monumens de l'antiquité, comme les anciennes médailles, les livres, les statues, les sculptures, les inscriptions, en un mot ce qui peut lui donner des lumieres à ce sujet . . . dont la fonction étoit de montrer les antiquités de la ville aux étrangers, de leur expliquer les inscriptions anciennes, \& de les assister de tout leur pouvoir dans ce genre d'érudition ». ${ }^{48}$ Johann Albert Fabricius, Bibliographia Antiquaria (Hamburg and Leipzig, 1713; 2n $^{\text {nd }}$ ed., Hamburg and Leipzig, 1716; $3^{\text {rd }}$ ed., ed. Paul Schaffshausen, Hamburg, 1760). For Fabricius see Erik Petersen, Johann Albert Fabricius: En Humanist i Europa, 2 vols. (Copenhagen, 1998).

${ }^{49}$ Anselmo Banduri, Numismata imperatorum Romanorum a Trajano Decio ad Palaeologos augustos: accessit Bibliotheca nummaria (Paris, 1718); Anselmo Banduri, 
Bibliotheca nummaria, ed. Johann Albert Fabricius (Hamburg, 1719); Johann Hübner, Bibliotheca Genealogica: Das ist: Ein Verzeichniss aller Alten und Neuen Genealogischen Bücher von allen Nationen in der Welt (Hamburg, 1729); Gerhard Ernst Franck de Franckenau, Bibliotheca Hispanica Historico-Genealogico-Heraldica (Leipzig, 1724).

${ }^{50}$ Johann Georg Graevius, Thesaurus antiquitatum Romanarum, 12 vols. (Leiden, 16941699); Jacobus Gronovius, Thesaurus Graecarum antiquitatum, 12 vols. (Leiden, 16971702); Hermann Adolph Meinders, Thesaurus antiquitatum Francicarum et Saxonicarum (Lemgo, 1710); Albert-Henri de Sallengre, Novus thesaurus antiquitatum Romanarum, 3 vols. (The Hague, 1716-1719); Johann Georg Graevius and Peter Burmann, Thesaurus antiquitatum et historiarum Italiae, 9 vols. in 45 (Leiden, 1704-1725); Johann Schilter, Thesaurus antiquitatum Teutonicarum, 3 vols. (Ulma, 1727-1728); Biagio Ugolini, Thesaurus antiquitatum sacrarum, 34 vols. (Venice, 1744-1769); Giovanni Vita, Thesaurus antiquitatum Beneventanarum (Rome, 1754); Giovanni Poleni, Utriusque thesauri antiquitatum Romanarum Graecarumque nova supplementa, 5 vols. (Venice, 1787). For an insight into the difficulties of assembling and publishing these vast compilations see Chiara Piccoli, 'Publishing in the Republic of Letters: Behind the Scenes of Pieter van der Aa's Thesaurus antiquitatum et historiarum Italiae (Leiden, 1704-25)', Quaerendo 43 (2013), 61-82.

${ }^{51}$ Fabricius, Bibliographia, ed. Schaffshausen, 180-181. ‘ . . . opus est non mediocri scientia Antiquitatis, qua destitutos nihil in priscorum scriptis videre, et e nostris moribus veteres aetates iudicando passim hallucinari certum est. Antiquitatis autem cognitionem ille demum sibi comparasse intelligitur, qui praeter Historiam veterem, tum fabularem illam tum veram huiusque partes ciuilem, ecclesiasticam, litterariam et naturalem perspectos habuerit ritus moresque veteres, sacros, politicos, militares et priuatos siue Oeconomicos, quique in monumentis antiquis probe sit versatus, as praeter libros editos consuluerit etiam ...'

${ }^{52}$ The fragments of Varro's Antiquitates were only collected and published as a separate work by Ausonius van Popma in 1601 (Varro, Operum quae exstant, ed. van Popma [Leiden, 1601]). 
${ }^{53}$ Flavio Biondo, Roma triumphans (Mantua, 1472); Johannes Rosinus, Romanarum antiquitatum libri decem ex variis scriptoribus summa fide singularique diligentia collecti (Basel, 1583). See also A. Mazzocco, 'Some Philological Aspects of Biondo Flavio's Roma Triumphans', Humanistica Lovaniensia 28 (1979), 1-26.

${ }^{54}$ Carlo Dati, Delle lodi del commendatores Cassiano Dal Pozzo orazione (Florence, 1664), and see Herklotz, Cassiano Dal Pozzo, 266-274.

${ }^{55}$ Bernard de Montfaucon, L'Antiquité expliquée et représentée en figures, 10 vols. (Paris, 1719-1724).

${ }^{56}$ Bibliotheca Duboisiana .. ., 4 vols. (The Hague, 1725), iv. 661. For an example of modern discomfort at early modern antiquarian land grabs see the pro-philological riposte by Dmitri Levitin, 'Egyptology, the Limits of Antiquarianism, and the Origins of Conjectural History, c.1680-1740: New Sources and Perspectives', History of European Ideas 41 (2015), 2-3.

${ }^{57}$ Jacques Spon, Miscellanea eruditae antiquitatis (Lyons, 1685), sig. ã3r-v. Beginning with Momigliano ('Ancient History and the Antiquarian', 300) Spon has received considerable attention, in large part due to his penchant for programmatic claims about the discipline within which he laboured. See Stark, Systematik und Geschichte, 137-139; Momigliano, 'Ancient History and the Antiquarian', 299-300; Miller, 'Writing Antiquarianism', 36-38.

${ }^{58}$ Spon, Miscellanea, sig. ã3v. 'Angeiographia instrumenta omnis generis domestica, militaria, nautica, vasa, mensuras, pondera scrutatur'.

${ }^{59}$ Spon, Miscellanea, sig. ã3v. 'Sunt \& aliae scientiae hisce subordinatae, aut per eas vagantes, veluti Dipnographia, quae convivial; Imantographia quae vestimenta; Doulographia quae servos; Taphographia quae funera explicant ...'

${ }^{60}$ Charles César Baudelot de Dairval, De l'utilité des voyages, et de l'avantage que la recherche des antiquitéz procure aux sçavans, 2 vols. (Paris, 1686).

${ }^{61}$ Daniel Georg Morhof, Polyhistor, literarius, philosophicus et practicus, 3rd ed., 3 vols. (Lübeck, 1732), i. 929.

${ }^{62}$ Friedrich August Wolf, Darstellung der Alterthumswissenschaft in Kleine Schriften, 2 vols., ed. Gottfried Bernhardy (Halle, 1869), ii. 894-895. 
${ }^{63}$ For historia literaria, one of the key sub-disciplines of the text-based antiquary, see Kelsey Jackson Williams, 'Canon before Canon, Literature before Literature: Thomas Pope Blount and the Scope of Early Modern Learning', Huntington Library Quarterly 77 (2014), 177-199.

${ }^{64}$ The concept of the 'third antiquity' was developed in Peter Burke, 'Images as Evidence in Seventeenth-Century Europe', Journal of the History of Ideas 64 (2003), 273-296. For Egypt see Brian A. Curran, The Egyptian Renaissance: The Afterlife of Ancient Egypt in Early Modern Italy (Chicago and London, 2007) and Daniel Stolzenberg, Egyptian Oedipus: Athanasius Kircher and the Secrets of Antiquity (Chicago and London, 2013). For Persia see Arthur John Booth, The Discovery and Decipherment of the Trilingual Cuneiform Inscriptions (London, 1902), chap. one, and Rudi Matthee, 'The Safavids under Western Eyes: Seventeenth-Century European Travelers to Iran', Journal of Early Modern History 13 (2009), 137-171. For Palmyra see Peter T. Daniels, "Shewing of hard sentences and dissolving of doubts': The First Decipherment', Journal of the American Oriental Society 108 (1988), 419-436, and Gregorio Astengo, 'The Rediscovery of Palmyra and its Dissemination in Philosophical Transactions', Notes and Records of the Royal Society, published online 16 March 2016. Momigliano had addressed the Italian study of the Etruscans in 'Ancient History and the Antiquarian', 304-307, 315-315. ${ }^{65}$ William Camden, Britannia sive florentissimorum regnorum, Angliae, Scotiae, Hiberniae chorographica descriptio (London, 1586; subsequent editions through 1607); Ole Worm, Danicorum monumentorum libri sex (Copenhagen, 1643); Philipp Clüver, Germaniae antiquae libri tres (Leiden, 1616; subsequent editions through 1663). ${ }^{66}$ Characteristic examples of each of these traditions include works such as, for England, William Burton, The Description of Leicestershire, Containing Matters of Antiquity, Historye, Armorye, and Genealogy (London, 1622), for Scotland, Patrick Abercromby, The Martial Atchievements of the Scots Nation, 2 vols. (Edinburgh, 1711-1715), and, for Sweden, Olof Verelius, ed., Gothrici \& Rolfi Westrogothiae regum historia lingua antiqua Gothica conscripta (Uppsala, 1664).

${ }^{67}$ Morhof, i. 930. 'Subjungimus Antiquarios Criticis, ut qui inter se sunt quam maximè cognati: in eâdem enim aurifodinâ utrique laborant ... » 
${ }^{68}$ e.g., in Miller, 'Writing Antiquarianism', 27 ('we still know almost nothing about the history of antiquarian scholarship'). The imagery of continental exploration has been regularly applied to the study of the Republic of Letters in recent decades, perhaps most memorably in essays such as Anthony Grafton, 'Latinland', Harvard Library Bulletin, N.S. 12 (2001), 5-12.

${ }^{69}$ For Ole Worm see Ole Peter Grell, 'In Search of True Knowledge: Ole Worm (15881654) and the New Philosophy', in Making Knowledge in Early Modern Europe: Practices, Objects, and Texts, 1400-1800, ed. Pamela H. Smith and Benjamin Schmidt (Chicago and London, 2007), 214-32, Ella Hoch, 'Diagnosing Fossilization in the Nordic Renaissance: An Investigation into the Correspondence of Ole Worm (1588-1654)', in A History of Geology and Medicine, ed. C. J. Duffin, et al. (London, 2013), 307-327, Klavs Randsborg, 'Ole Worm: An Essay on the Modernization of Antiquity', Acta Archaeologica 65 (1994), 135-69, H. D. Schepelern, 'Museum Wormianum: dets forudsætninger og tilblivelse' (Copenhagen University Doctoral Thesis, 1971), as well as the Latin and Danish editions of his letters, Olai Wormii et ad eum doctorum virorum epistolae, 2 vols. (Copenhagen, 1751) and Breve fra og til Ole Worm, 3 vols., ed. H. D. Schepelern (Copenhagen, 1965-8). For later Anglophone reception of the Scandinavian tradition of which Worm was a part see Kelsey Jackson Williams, 'Thomas Gray and the Goths: Philology, Poetry, and the Uses of the Norse Past in Eighteenth-Century England', Review of English Studies 65 (2014), 694-710.

${ }^{70}$ C. F. Bricka, et al., eds., Dansk Biografisk Leksikon, 27 vols. (Copenhagen, 1933-1944), xxvi. 279-280.

${ }^{71}$ Worm, Epistolae, i. 41-51.

${ }^{72}$ Dansk Biografisk Leksikon, xxvi. 284.

${ }^{73}$ Ole Worm, Fasti Danici (Copenhagen, 1626), [Runir] seu Danica literatura antiquissima (Copenhagen, 1636), and Danicorum monumentorum libri sex (Copenhagen, 1643).

${ }^{74}$ Worm, Monumenta Danica, 1-99.

${ }^{75}$ For Aubrey see Michael Hunter, John Aubrey and the Realm of Learning (London, 1975), Kelsey Jackson Williams, The Antiquary: John Aubrey's Historical Scholarship 
(Oxford, 2016), and Kelsey Jackson Williams, ‘Training the Virtuoso: John Aubrey's Education and Early Life', The Seventeenth Century 27 (2012), 157-182, together with John Aubrey, Brief Lives with an Apparatus for the Lives of our English Mathematical Writers, 2 vols., ed. Kate Bennett (Oxford, 2015).

${ }^{76}$ The boldest claims for Aubrey as a proto-modern archaeologist appear in Schnapp, Discovery, 188-196, but see Jackson Williams, The Antiquary, chaps. 1-2.

${ }^{77}$ For Innes see David Allan, 'Historiography of the Scottish Enlightenment', in A Companion to Enlightenment Historiography, ed. Sophie Bourgault and Robert Sparling (Leiden, 2013), 307-342, Colin Kidd, 'Antiquarianism, Religion, and the Scottish Enlightenment', Innes Review 46 (1995), 139-154, and James F. McMillan, 'Thomas Innes and the Bull 'Unigenitus', Innes Review 33 (1982), 23-30, as well as Thomas Innes, A Critical Essay of the Ancient Inhabitants of the Northern Parts of Britain, or Scotland, 2 vols. (London, 1729), The Civil and Ecclesiastical History of Scotland, ed. George Grub (Aberdeen, 1853), and 'Papers by Father Innes', in the Miscellany of the Spalding Club, Vol. 2 (Aberdeen, 1842), 353-380. The present author will consider Innes and his relationship to European antiquarianism in more detail in a forthcoming monograph.

${ }^{78}$ ODNB, s.n.

${ }^{79}$ Charta authentica Robert Senschalli Scotiae: ex archivo Collegii Scotorum Parisiensis edita (Paris, 1695), to be read in conjunction with Innes's account of the document's discovery in 'Papers by Father Innes', 370-371.

${ }^{80}$ Innes, Critical Essay and Civil and Ecclesiastical History. The chronology survives only in a later manuscript copy made by James Chalmers, now at National Library of Scotland Adv. MS 22.2.7.

${ }^{81}$ George Mackenzie, The Lives and Characters of the Most Eminent Writers of the Scots Nation, 3 vols. (Edinburgh, 1708-1722), ii. 294. Nor did recognition of Selden's polymathy abrogate his right to the title of antiquary; cf. his translator Adam Littleton's paean proving 'what a Scholar, a Philologer, a Humanist, a Linguist, a Lawyer, a Critick, an Antiquary, and (which proves him an absolute Master of all these and many other 
Knowledges) what a Writer, the Great SELDEN was' (John Selden, The Reverse or Backface of the English Janus, trans. Adam Littleton [London, 1682], sig. A3r).

${ }^{82}$ Worm, Fasti Danici. See also Carla Cucina, 'Traces of Runic Lore in Italy: The Wooden Calendar 'Book' in Bologna and Its Medieval Connections', Classiconorroena 29 (2011), 156-157.

${ }^{83}$ See Worm, Danica literatura antiquissima and Monumenta Danica.

${ }^{84}$ Jean-Baptiste Thiers, Histoire des perruques ou l'on fait voir leur origine, leur usage, leur former, l'abus \& l'irregularité de celles des Ecclesiastiques (Paris, 1690), later translated as Historia von Ursprung Bebrauch und Gestalt der Perruquen (Frankfurt, 1692); Johann Gerhard Meuschen, Disquisitio philologica de ritu salutandi sternutantes (Kiel, 1704).

${ }^{85}$ Research into the early modern study of the history of religion is a field in its own right and has been given accordingly less weight in the present article. See, amongst many others, Guy Stroumsa, A New Science: The Discovery of Religion in the Age of Reason (Cambridge, Mass., 2010).

${ }^{86}$ Philippe Labbe, Bibliotheca bibliothecarum curis secundis auctior; Accedit Bibliotheca nummaria in duas partes tributa, 2nd ed. (Rouen, 1672). See, however, Thierry Sarmant, Le république des médailles: numismates et collections numismatiques à Paris du Grand Siècle au siècle des Lumières (Paris, 2003), M. H. Crawford, C. R. Ligota, and J. B. Trapp, eds., Medals and Coins from Budé to Mommsen (London, 1990), Numismatische Literatur 1500-1864: die Entwicklung der Methoden einer Wissenchaft, ed. Peter Berghaus (Wiesbaden, 1995), and John Cunnally, Images of the Illustrious: The Numismatic Presence in the Renaissance (Princeton, 1999). Comprehensive bibliographies of sixteenth- and seventeenth-century numismatic scholarship can be found in C. E. Dekesel, Bibliotheca Nummaria: Bibliography of 16th Century Numismatic Books (London, 1997) and C. E. Dekesel, Bibliotheca Nummaria II: Bibliography of 17th Century Numismatic Books, 3 vols. (London, 2003).

${ }^{87}$ William Stenhouse, Reading Inscriptions and Writing Ancient History: Historical Scholarship in the Late Renaissance (London, 2005). A history of epigraphy following on from Stenhouse might begin with Jan Gruter, Inscriptiones antiquae totius orbis 
Romani (Heidelberg, 1603) and continue with his imitators and editors: Thomas Reinesius, Syntagma inscriptionum antiquarum cumprimis Roma veteris: quarum omissa est recensio in vasto Jani Gruteri opere cujus isthoc dici possit Supplementum (Leipzig, 1682), and Jan Gruter, Inscriptiones antiquae totius orbis Romani, 2 vols. in 4, ed. Johann Georg Graevius, Marquard Gude, et al. (Amsterdam, 1707), paying particular attention to Scipione Maffei's 'Ars critica lapidaria', which was published in the first volume of Sebastiano Donato's Ad novum thesaurum veterum inscriptionum $\mathrm{Cl}$. $\mathrm{V}$. Ludovici Antonii Muratorii supplementem, 2 vols. (Lucca, 1765).

${ }^{88}$ Marie Tanner, The Last Descendant of Aeneas: The Hapsburgs and the Mythic Image of the Emperor (New Haven and London, 1993); Roberto Bizzocchi, Genealogie incredibili: Scritti di storia nell'Europa moderna, new ed. (Bologna, 2009). Key texts in the evolution of this genealogical tradition include Hieronymus Henninges, Theatrum genealogicum, 4 vols. (Magdeburg, 1598), Philipp Jakob Spener, Theatrum nobilitatis Europae, 4 vols. (Frankfurt, 1668-1678), and the writings of the prolific Baroque genealogists Johann Seifert (see Hübner, Bibliotheca, 363-364) and Jacob Wilhelm von Imhof. See also the French tradition of histoire genealogique deriving from the works of André Duchesne (Hübner, Bibliotheca, 112-119), discussed in Harold A. Ellis, 'Genealogy, History, and Aristocratic Reaction in Early Eighteenth-Century France: The Case of Henri de Boulainvilliers', Journal of Modern History 58 (1986), 414-451. For works on standards of legal proof required in genealogies see Charles-François Menestrier, Les diverses especes de noblesse, et les manieres d'en dresser les preuves (Paris, 1682) and Felix Heinrich Hildebrand, Dissertatio iuridica inauguralis de probatione per stemma genealogica (Altdorf, 1719).

${ }^{89}$ Hübner was a significant genealogist in his own right, compiling the Genealogische Tabellen, 4 vols. (Leipzig, 1708-1733) upon which James Anderson based his Royal Genealogies: or, the Genealogical Tables of Emperors, Kings and Princes, from Adam to these Times (London, 1732).

${ }^{90}$ Aubrey's epigraphic and numismatic studies are at John Aubrey, Monumenta

Britannica, 2 vols., ed. Rodney Legge and John Fowles (Sherborne, Dorset, 1980-1982), i. 455 and ii. 963-970. Innes's involvement in preparing a genealogical proof of nobility 
for one of the grandsons of the formidable Anglo-Scots Jacobite Charlotte Bulkeley, Viscountess Clare, is detailed by him in a letter to Harry Maule of Kellie dated 10 September 1733 (British Library Add. MS 39923, fols. 51-52).

${ }^{91}$ See, for example, the definition given--but then immediately problematized--by Alain Schnapp: 'It was the historian's job to comment on texts; the antiquarian looked after material remains' ('The Roots of Antiquarianism' in World Antiquarianism, ed. Schnapp, 1).

${ }^{92}$ For these debates see Randolph C. Head, 'Documents, Archives and Proof around 1700', The Historical Journal 56 (2013), 909-930, who emphasises their importance in the development of early modern theories of the archive, and Alfred Hiatt, 'Diplomatic Arts: Hickes against Mabillon in the Republic of Letters', Journal of the History of Ideas 70 (2009), 351-373. See also Harry Bresslau, Handbuch der Urkundenlehre für Deutschland und Italien, 2nd ed., 3 vols. (Leipzig, 1912-1931), i. 11-45.

${ }^{93}$ Daniel Papebroch, 'Propylaeum antiquarium circa veri ac falsi discrimen in vetustis membranis', in Acta Sanctorum, Aprilis tomus secundus (1675; reprinted, Paris and Rome, 1866), I-LII.

${ }^{94}$ For the methods of Valla's exposé see Salvatore I. Camporeale, 'Lorenzo Valla's Oratio on the Pseudo-Donation of Constantine: Dissent and Innovation in Early Renaissance Humanism', Journal of the History of Ideas 57 (1996), 9-26. ${ }^{95}$ Jean Mabillon, De re diplomatica libri sex (Paris, 1681). See also the outline and summary by Jakub Zouhar, 'De re diplomatica libri sex by Jean Mabillon in Outline', Listy filologické 133 (2010), 357-388, who trenchantly observes (363) that a sure sign of Mabillon's classic status is that he is widely quoted but rarely read.

${ }^{96}$ John Aubrey, 'Chronologia Graphica', Bodleian Library, Oxford MS Top. Gen. c. 25, fols. 185r-196r (Aubrey had conceived of the project in 1672, but only worked it out in full in 1689 after Mabillon's work had become known in England).

${ }^{97}$ Anthony Grafton, Joseph Scaliger: A Study in the History of Classical Scholarship, 2 vols. (Oxford, 1983-1993), i. passim. 
${ }^{98}$ Barthélémy Germon, De veteribus regum Francorum diplomatibus (Paris, 1703); George Hickes, Linguarum vett. septentrionalium thesaurus grammatico-criticus et archaeologicus, 2 vols. (Oxford, 1705).

${ }^{99}$ Bernard de Montfaucon, Palaeographia Graeca (Paris, 1708). For Mabillon's reception in Italy see Arnaldo Momigliano, 'Mabillon's Italian Disciples', in Essays in Ancient and Modern Historiography (Oxford, 1977), 277-293.

${ }^{100}$ James Anderson and Thomas Ruddiman, Selectus diplomatum \& numismatum Scotiae thesaurus (Edinburgh, 1739).

${ }^{101}$ The manuscript sources are edited at Innes, Critical Essay, ii. 761-839. For an example of his commentary on an individual manuscript--the Chronica de origine antiquorum Pictorum--see ibid., i. 105-106.

${ }^{102}$ For an example of the denigration of local oral tradition see the caustic discussion of the 'Country People' who 'talk likewise of Vaults under Ground, haunted with spirits, and such like ignorant Stuff' at Alexander Gordon, Itinerarium Septentrionale: or, a Journey thro' Most of the Counties of Scotland and Those in the North of England (London, 1726), 21.

${ }^{103}$ Jackson Williams, The Antiquary, chap. 5.

${ }^{104}$ See Jan Broadway, 'No historie so meete': Gentry Culture and the Development of Local History in Elizabethan and Early Stuart England (Manchester, 2006).

${ }^{105}$ See Graham Parry, The Trophies of Time: English Antiquarians of the Seventeenth Century (Oxford, 1995), chap. 10, and Olivie Horsfall Turner, "The Windows of this Church are of several Fashions': Architectural Form and Historical Method in John Aubrey's 'Chronologia Architectonica”, Architectural History 54 (2011), 171-193. ${ }^{106}$ Ernst Ekman, 'Gothic Patriotism and Olof Rudbeck', Journal of Modern History 34 (1962), 52-63; Stina Hansson, 'The Lament of the Swedish Language: Sweden's Gothic Renaissance', Renaissance Studies 23 (2009), 151-160.

${ }^{107}$ Allan Ellenius, 'Johannes Schefferus and Swedish Antiquity', Journal of the Warburg and Courtauld Institutes 20 (1957), 59-74, and Jackson Williams, The Antiquary, 37-41. 
${ }^{108}$ Jason Harris, 'Exiles and Saints in Baroque Europe: George Conn and the Scotic Debate', in The Ulster Earls and Baroque Europe: Refashioning Irish Identities, 16001800, ed. Thomas O’Connor and Mary Ann Lyons (Dublin, 2010), 306-326.

${ }^{109}$ William Ferguson, The Identity of the Scottish Nation: An Historic Quest (Edinburgh, 1998), 157-169.

${ }^{110}$ For a key example of this see Thomas Innes's letter to James VIII and III, dated 17 October 1729, in which he explains his motivations for writing the Critical Essay ('Papers by Father Innes', 353-356).

${ }^{111}$ Anthony Grafton and Joanna Weinberg, 'I have always loved the Holy Tongue': Isaac Casaubon, the Jews, and a Forgotten Chapter in Renaissance Scholarship (Cambridge, Mass., and London, 2011), chap. 4.

${ }^{112}$ Peter N. Miller, 'The 'Antiquarianization' of Biblical Scholarship and the London Polyglot Bible (1653-57)', Journal of the History of Ideas 62 (2001), 463-482 at 464, quoting Thomas Fuller, The Holy State (Cambridge, 1642), 69-72, which goes on to describes the 'true Church Antiquary' as 'a traveller into former times, whence he hath learnt their language and fashions. If he meets with an old manuscript, which hath the mark worn out of its mouth, and hath lost the date, yet he can tell the age thereof either by the phrase or character' (69). For another example of the theological implications of antiquarian and philological scholarship see Anthony Ossa-Richardson, The Devil's Tabernacle: The Pagan Oracles in Early Modern Thought (Princeton and Oxford, 2013). 113 Thomas Innes, 'Mémoire pour servir a une dissertation sur l'ancienne liturgie d'Ecosse', Scottish Catholic Archives, P/2/7/1; The Civil and Ecclesiastical History of Scotland, ed. George Grub (Aberdeen, 1853).

${ }^{114}$ Parry, Trophies of Time, 228.

${ }^{115}$ Williams, The Antiquary, 117.

${ }^{116}$ Notably in Miller, 'Tentative Morphology'.

${ }^{117}$ See Miller, 'Writing Antiquarianism' and the reflections in Giovanna Ceserani, 'Antiquarian Transformations in Eighteenth-Century Europe', in World Antiquarianism, ed. Schnapp, 317-342. 
${ }^{118}$ See, for an example of such a reconsideration, Suzanne Marchand, 'From Antiquarian to Archaeologist? Adolf Furtwängler and the Problem of 'Modern' Classical Archaeology', in Momigliano and Antiquarianism, ed. Miller, 248-285.

${ }^{119}$ For this rump in a British context see Battles, Antiquarian Impulse and Philippa Levine, The Amateur and the Professional: Antiquarians, Historians and Archaeologists in Victorian England, 1838-1886 (Cambridge, 1986).

${ }^{120}$ Levine, Amateur and the Professional, 12, quoting Sir John Simeon, c.1859.

${ }^{121}$ William Forbes Skene, Celtic Scotland, 3 vols. (Edinburgh, 1876-1880). See James Anderson, 'William Forbes Skene: Celtic Scotland v. Caledonia', Scottish Historical Review 46 (1967), 140-150, and W. D. H. Sellar, 'William Forbes Skene (1809-92), Historians of Celtic Scotland', Proceedings of the Society of Antiquaries of Scotland 131 (2001), 3-21.

${ }^{122}$ For the Scandinavian context see Ole Klindt-Jensen, A History of Scandinavian Archaeology, trans. Russell G. Poole (London, 1975). For Aubrey and Piggott see the latter's Ruins in a Landscape: Essays in Antiquarianism (Edinburgh, 1976) and Ancient Britons and the Antiquarian Imagination: Ideas from the Renaissance to the Regency (London, 1989).

${ }^{123}$ Parry, Trophies of Time, Vine, In Defiance of Time, and Klindt-Jensen, History of Scandinavian Archaeology.

${ }^{124}$ J. G. A. Pocock's Barbarism and Religion, 6 vols. (Cambridge, 1999-2010), though dauntingly comprehensive, focuses more on Gibbon's grand narrative than on the erudite nuts and bolts of his engagement with antiquarian texts.

${ }^{125}$ Anthony Grafton, ‘From Politian to Pasquali’, Journal of Roman Studies 67 (1977), 176.

${ }^{126}$ Christopher S. Wood, 'The Credulity Problem', in Antiquarianism and Intellectual Life, ed. Miller and Louis, 156.

${ }^{127}$ For Annius of Viterbo see Anthony Grafton, Defenders of the Text: The Traditions of Scholarship in an Age of Science, 1450-1800 (Cambridge, Mass., 1991), 76-103, and Walter Stephens, 'When Pope Noah Ruled the Etruscans: Annius of Viterbo and his Forged Antiquities', Modern Language Notes 119 (2004), S201-S223; for Rudbeck, 
Gunnar Eriksson, The Atlantic Vision: Olaus Rudbeck and Baroque Science (Canton, Mass., 1994) and Kelsey Jackson Williams and William Poole, 'A Swede in Restoration Oxford: Gothic Patriots, Swedish Books, English Scholars', Lias 39 (2012), 1-67; and for Stukeley, Stuart Piggott, William Stukeley: An Eighteenth-Century Antiquary, $2^{\text {nd }}$ ed. (London, 1985) and David Boyd Haycock, William Stukeley: Science, Religion and Archaeology in Eighteenth-Century England (Woodbridge, 2002).

${ }^{128}$ As well as 'The Credulity Problem' see Forgery, Replica, Fiction: Temporalities of German Renaissance Art (Chicago and London, 2008) and Alexander Nagel and Wood, Anachronic Renaissance (New York, 2010).

${ }^{129}$ Wood, 'Credulity Problem', 162.

${ }^{130}$ Wood, ‘Credulity Problem', 166-167.

${ }^{131}$ William Somner, The Antiquities of Canterbury (London, 1640), sig. *v.

${ }^{132}$ Somner, Antiquities, sig. **2v.

${ }^{133}$ Somner, Antiquities, sig. **3v.

${ }^{134}$ James Wright, The History and Antiquities of the County of Rutland (London, 1684), preface.

${ }^{135}$ Selden, English Janus, sig. a2r; William Lambarde, A Perambulation of Kent: Conteining the Description, Hystorie, and Customes of that Shyre (London, 1576), sig. giijr.

${ }^{136}$ Robert Plot, The Natural History of Oxford-shire, Being an Essay toward the Natural History of England (Oxford, 1677), preface.

${ }^{137}$ Nicola Francesco Haym, The British Treasury, 2 vols. (London, 1719), i. sig. A2r;

Thomas Hearne, The Itinerary of John Leland the Antiquary, 2 vols. (Oxford, 1711), i. 64-65.

138 'Life of Mr. Camden' in Camden's Britannia Abridg'd, Vol. I (London, 1701), sig. A7r.

${ }^{139}$ Burton, Description of Leicestershire, sig. I2r. 